\title{
LEVEL II SCOUR ANALYSIS FOR BRIDGE 29 (HUNTTH00290029) on TOWN HIGHWAY 29, crossing COBB BROOK, HUNTINGTON, VERMONT \\ U.S. Geological Survey Open-File Report 97-652
}




\section{LEVEL II SCOUR ANALYSIS FOR BRIDGE 29 (HUNTTH00290029) on TOWN HIGHWAY 29, crossing COBB BROOK, HUNTINGTON, VERMONT By ROBERT H. FLYNN}

U.S. Geological Survey Open-File Report 97-652

Prepared in cooperation with

VERMONT AGENCY OF TRANSPORTATION and

FEDERAL HIGHWAY ADMINISTRATION 


\title{
U.S. DEPARTMENT OF THE INTERIOR BRUCE BABBITT, Secretary
}

\author{
U.S. GEOLOGICAL SURVEY \\ Gordon P. Eaton, Director
}

For additional information write to:

District Chief

U.S. Geological Survey 361 Commerce Way

Pembroke, NH 03275-3718
Copies of this report may be purchased from:

U.S. Geological Survey

Branch of Information Services

Open-File Reports Unit

Box 25286

Denver, CO 80225-0286 


\section{CONTENTS}

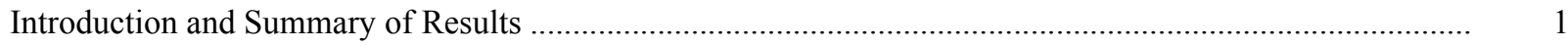

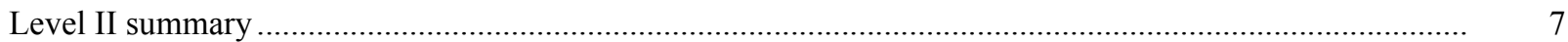

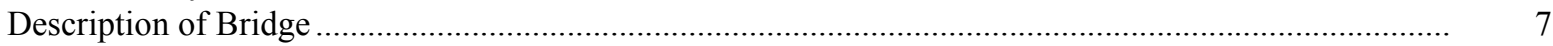

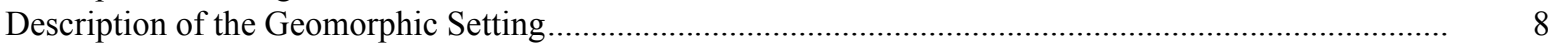

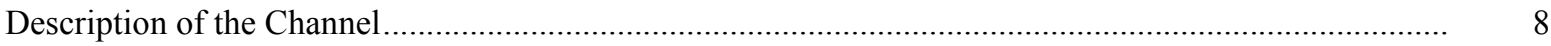

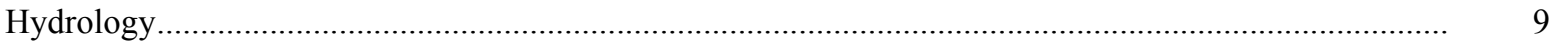

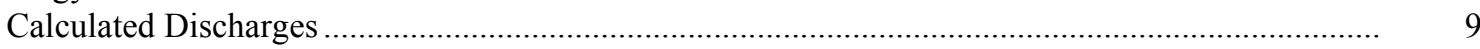

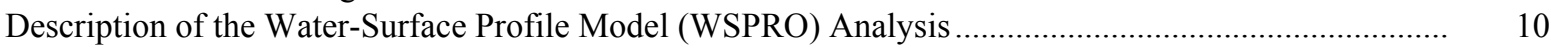

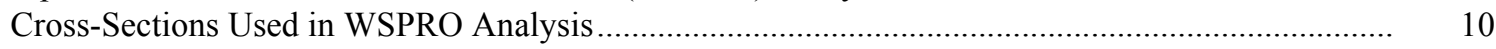

Data and Assumptions Used in WSPRO Model ...................................................................... 11

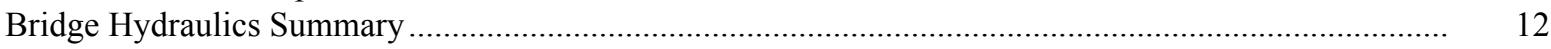

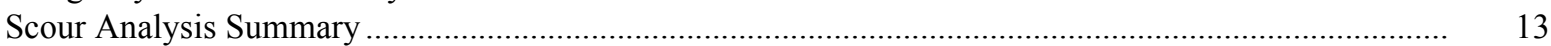

Special Conditions or Assumptions Made in Scour Analysis ...................................................... 13

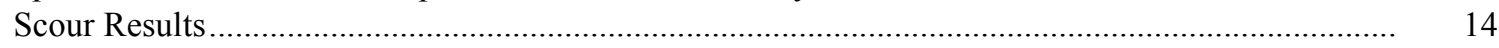

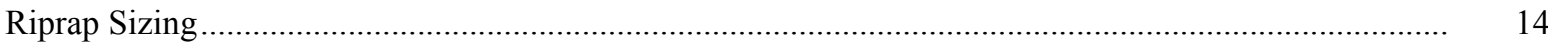

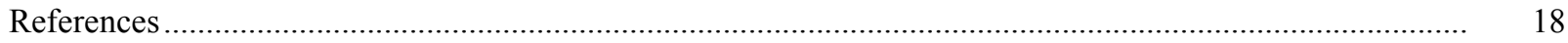

Appendixes:

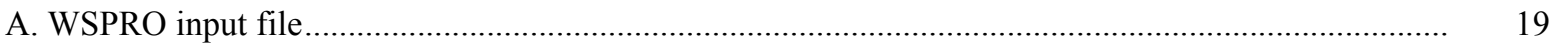

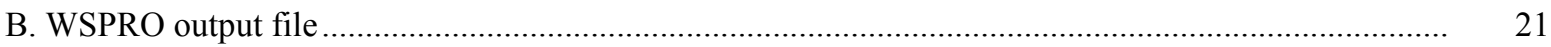

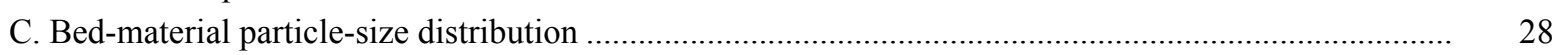

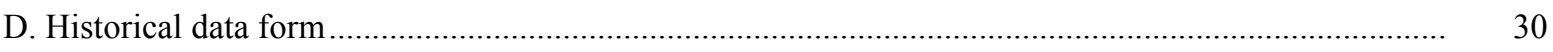

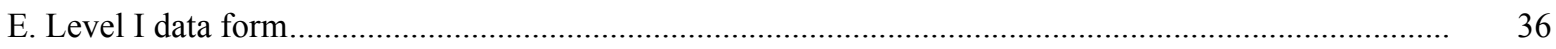

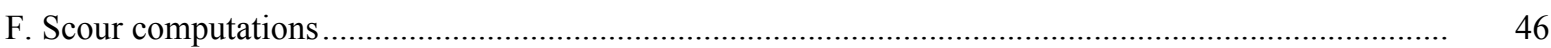

\section{FIGURES}

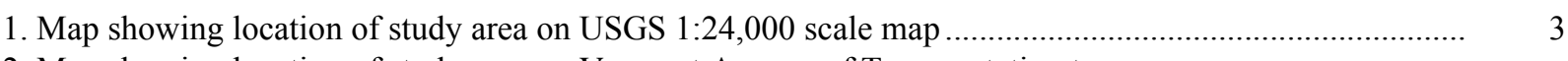

2. Map showing location of study area on Vermont Agency of Transportation town
highway map

3. Structure HUNTTH00290029 viewed from upstream (June 25, 1996) ..................................................

4. Downstream channel viewed from structure HUNTTH00290029 (June 25, 1996)............................. 5

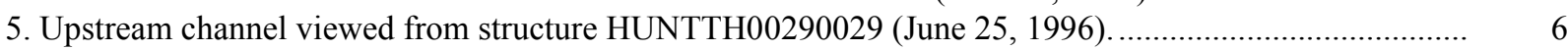

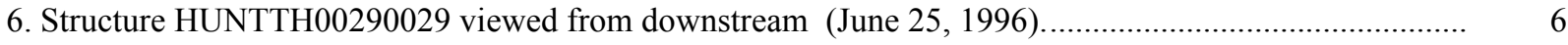

7. Water-surface profiles for the 100- and 500-year discharges at structure

HUNTTH00290029 on Town Highway 29, crossing Cobb Brook,

Huntington, Vermont.

8. Scour elevations for the 100- and 500-year discharges at structure

HUNTTH00290029 on Town Highway 29, crossing Cobb Brook,

Huntington, Vermont.

\section{TABLES}

1. Remaining footing/pile depth at abutments for the 100-year discharge at structure

HUNTTH00290029 on Town Highway 29, crossing Cobb Brook,

Huntington, Vermont....

2. Remaining footing/pile depth at abutments for the 500-year discharge at structure

HUNTTH00290029 on Town Highway 29, crossing Cobb Brook,

Huntington, Vermont.

3
4
5
5
6
6




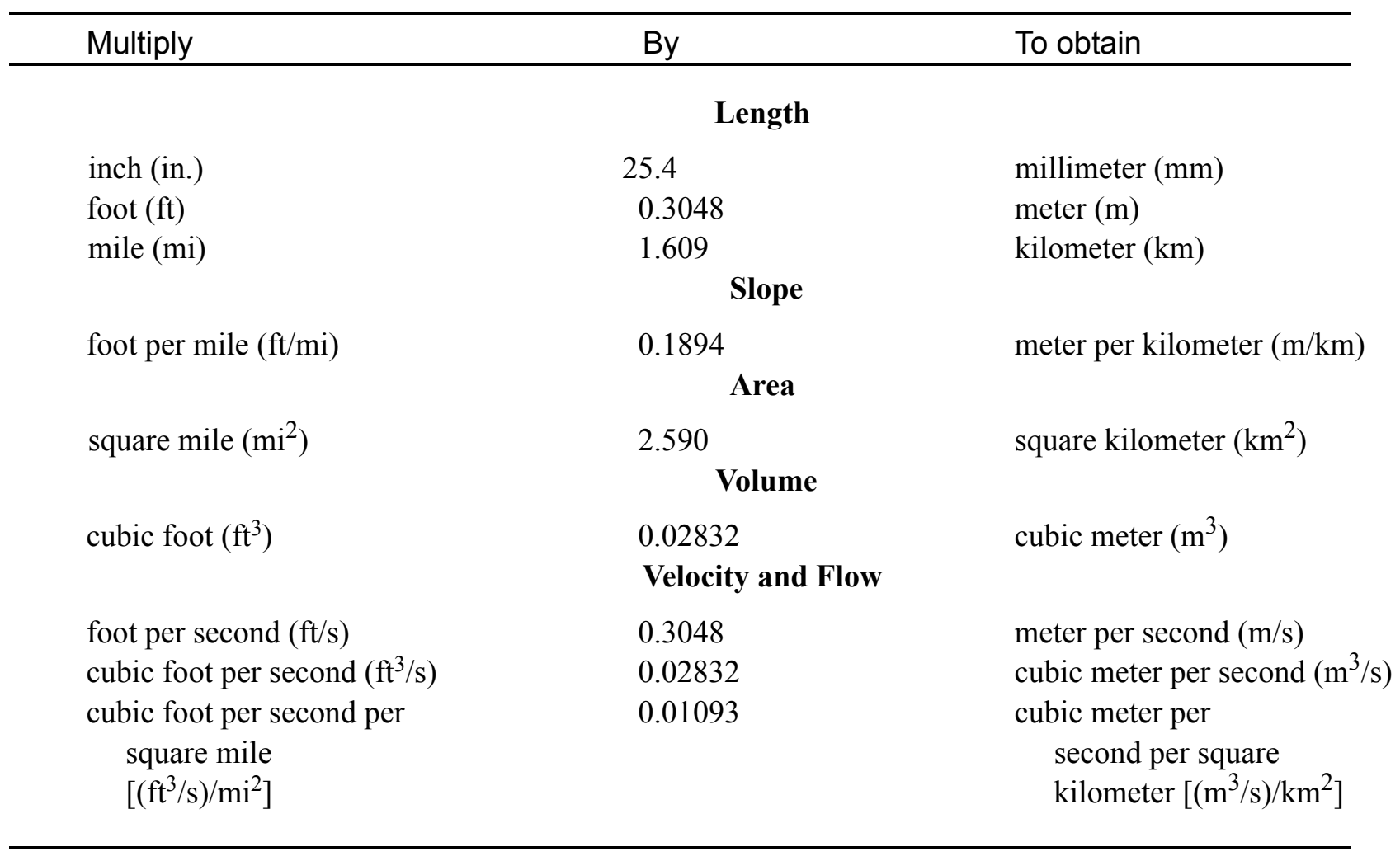

\section{OTHER ABBREVIATIONS}

$\begin{array}{lrlr}\mathrm{BF} & \text { bank full } & \text { LWW } & \text { left wingwall } \\ \mathrm{cfs} & \text { cubic feet per second } & \text { MC } & \text { main channel } \\ \mathrm{D}_{50} & \text { median diameter of bed material } & \text { RAB } & \text { right abutment } \\ \mathrm{DS} & \text { downstream } & \text { RABUT } & \text { face of right abutment } \\ \mathrm{elev} & \text { elevation } & \text { RB } & \text { right bank } \\ \mathrm{f} / \mathrm{p} & \text { flood plain } & \text { ROB } & \text { right overbank } \\ \mathrm{ft}^{2} & \text { square feet } & \text { RWW } & \text { right wingwall } \\ \mathrm{ft} / \mathrm{ft} & \text { feet per foot } & \text { TH } & \text { town highway } \\ \mathrm{JCT} & \text { junction } & \text { UB } & \text { under bridge } \\ \mathrm{LAB} & \text { left abutment } & \text { US } & \text { upstream } \\ \mathrm{LABUT} & \text { face of left abutment } & \text { USGS } & \text { United States Geological Survey } \\ \mathrm{LB} & \text { left bank } & \text { VTAOT Vermont Agency of Transportation } \\ \mathrm{LOB} & \text { left overbank } & \text { WSPRO } & \text { water-surface profile model }\end{array}$

In this report, the words "right" and "left" refer to directions that would be reported by an observer facing downstream. Sea level: In this report, "sea level" refers to the National Geodetic Vertical Datum of 1929-- a geodetic datum derived from a general adjustment of the first-order level nets of the United States and Canada, formerly called Sea Level Datum of 1929.

In the appendices, the above abbreviations may be combined. For example, USLB would represent upstream left bank. 


\title{
LEVEL II SCOUR ANALYSIS FOR BRIDGE 29 (HUNTTH00290029) ON TOWN HIGHWAY 29, CROSSING COBB BROOK, HUNTINGTON, VERMONT
}

\author{
By Robert H. Flynn
}

\section{INTRODUCTION AND SUMMARY OF RESULTS}

This report provides the results of a detailed Level II analysis of scour potential at structure HUNTTH00290029 on Town Highway 29 crossing Cobb Brook, Huntington, Vermont (figures 1-8). A Level II study is a basic engineering analysis of the site, including a quantitative analysis of stream stability and scour (U.S. Department of Transportation, 1993). Results of a Level I scour investigation also are included in Appendix E of this report. A Level I investigation provides a qualitative geomorphic characterization of the study site. Information on the bridge, gleaned from Vermont Agency of Transportation (VTAOT) files, was compiled prior to conducting Level I and Level II analyses and is found in Appendix D.

The site is in the Green Mountain section of the New England physiographic province in northwestern Vermont. The $4.16-\mathrm{mi}^{2}$ drainage area is in a predominantly rural and forested basin. In the vicinity of the study site, the surface cover is forest upstream and downstream of the bridge.

In the study area, Cobb Brook has an incised, straight channel with a slope of approximately $0.024 \mathrm{ft} / \mathrm{ft}$, an average channel top width of $53 \mathrm{ft}$ and an average bank height of $4 \mathrm{ft}$. The channel bed material ranges from gravel to bedrock with a median grain size $\left(D_{50}\right)$ of 112.0 $\mathrm{mm}(0.367 \mathrm{ft})$. The geomorphic assessment at the time of the Level I and Level II site visit on June 25,1996 , indicated that the reach was stable.

The Town Highway 29 crossing of Cobb Brook is a 36-ft-long, one-lane bridge consisting of one 30-foot steel-beam span (Vermont Agency of Transportation, written communication, December 11,1995) and a wooden deck. The opening length of the structure parallel to the bridge face is $27 \mathrm{ft}$.The bridge is supported by vertical, concrete abutments. The channel is skewed approximately 25 degrees to the opening while the opening-skew-to-roadway was measured to be 20 degrees. VTAOT records indicate an opening-skew-to-roadway of zero degrees. 
A scour hole $1.5 \mathrm{ft}$ deeper than the mean thalweg depth was observed extending from $12 \mathrm{ft}$ upstream of the upstream end of the left abutment to $10 \mathrm{ft}$ under the bridge in the center of the channel during the Level I assessment. Another scour hole approximately $1.2 \mathrm{ft}$ deeper than the mean thalweg depth was observed along the downstream end of the right abutment during the Level I assessment. The scour protection measures at the site included type-2 stone fill (less than 36 inches diameter) along the upstream end of the right abutment and type-3 stone fill (less than 48 inches diameter) along the upstream end of the upstream left retaining wall. Additional details describing conditions at the site are included in the Level II Summary and Appendices D and E.

Scour depths and recommended rock rip-rap sizes were computed using the general guidelines described in Hydraulic Engineering Circular 18 (Richardson and others, 1995). Total scour at a highway crossing is comprised of three components: 1) long-term streambed degradation; 2) contraction scour (due to accelerated flow caused by a reduction in flow area at a bridge) and; 3 ) local scour (caused by accelerated flow around piers and abutments). Total scour is the sum of the three components. Equations are available to compute depths for contraction and local scour and a summary of the results of these computations follows.

Contraction scour for all modelled flows was computed to be zero $\mathrm{ft}$. Abutment scour ranged from 9.9 to $12.5 \mathrm{ft}$ along the left abutment and from 6.2 to $8.6 \mathrm{ft}$ along the right abutment. The worst-case abutment scour occurred at the 500-year discharge. Additional information on scour depths and depths to armoring are included in the section titled "Scour Results". Scoured-streambed elevations, based on the calculated scour depths, are presented in tables 1 and 2. A cross-section of the scour computed at the bridge is presented in figure 8. Scour depths were calculated assuming an infinite depth of erosive material and a homogeneous particle-size distribution.

It is generally accepted that the Froehlich equation (abutment scour) gives "excessively conservative estimates of scour depths" (Richardson and others, 1995, p. 47). Usually, computed scour depths are evaluated in combination with other information including (but not limited to) historical performance during flood events, the geomorphic stability assessment, existing scour protection measures, and the results of the hydraulic analyses. Therefore, scour depths adopted by VTAOT may differ from the computed values documented herein. 


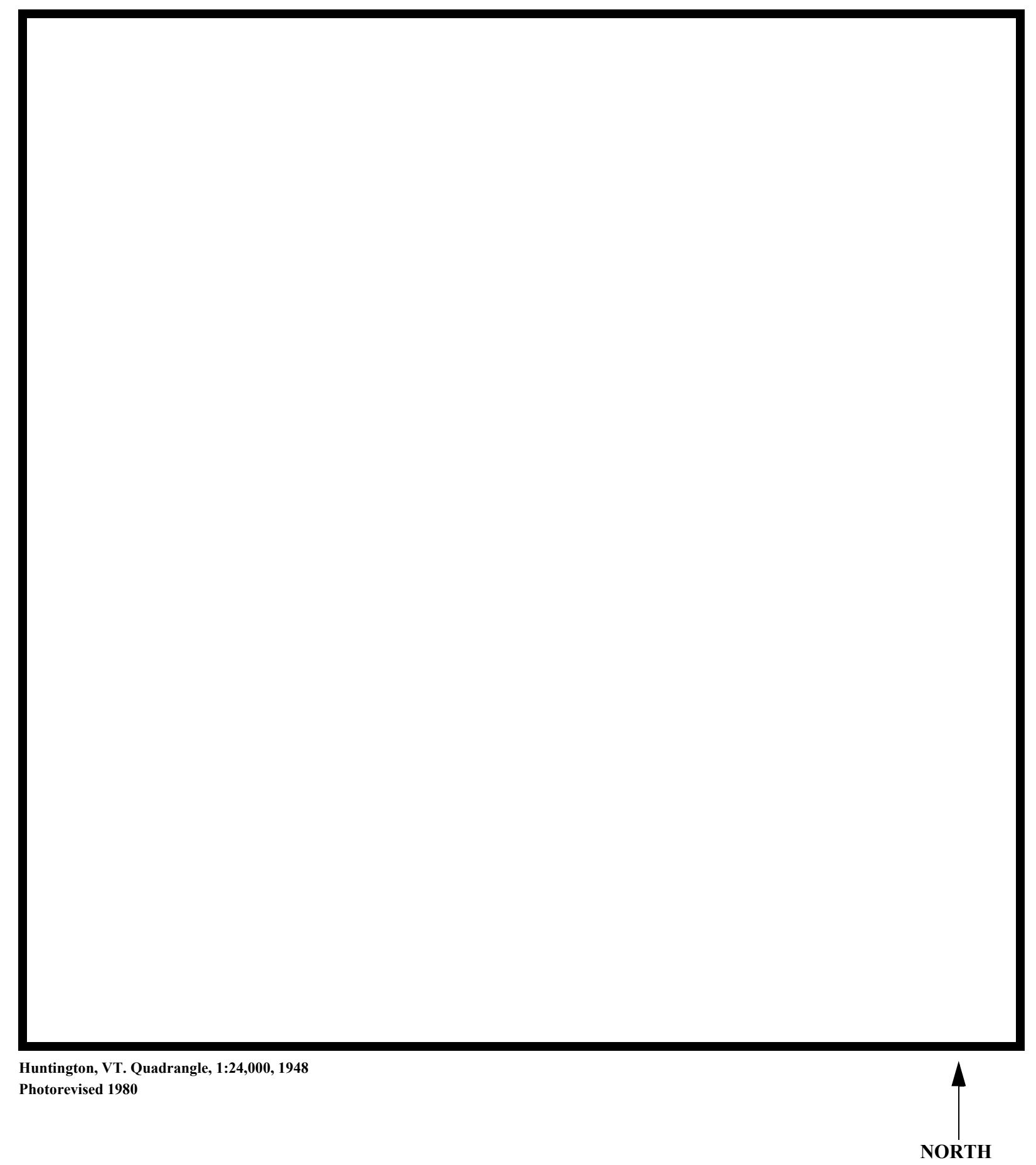

Figure 1. Location of study area on USGS 1:24,000 scale map. 
Figure 2. Location of study area on Vermont Agency of Transportation town highway map. 

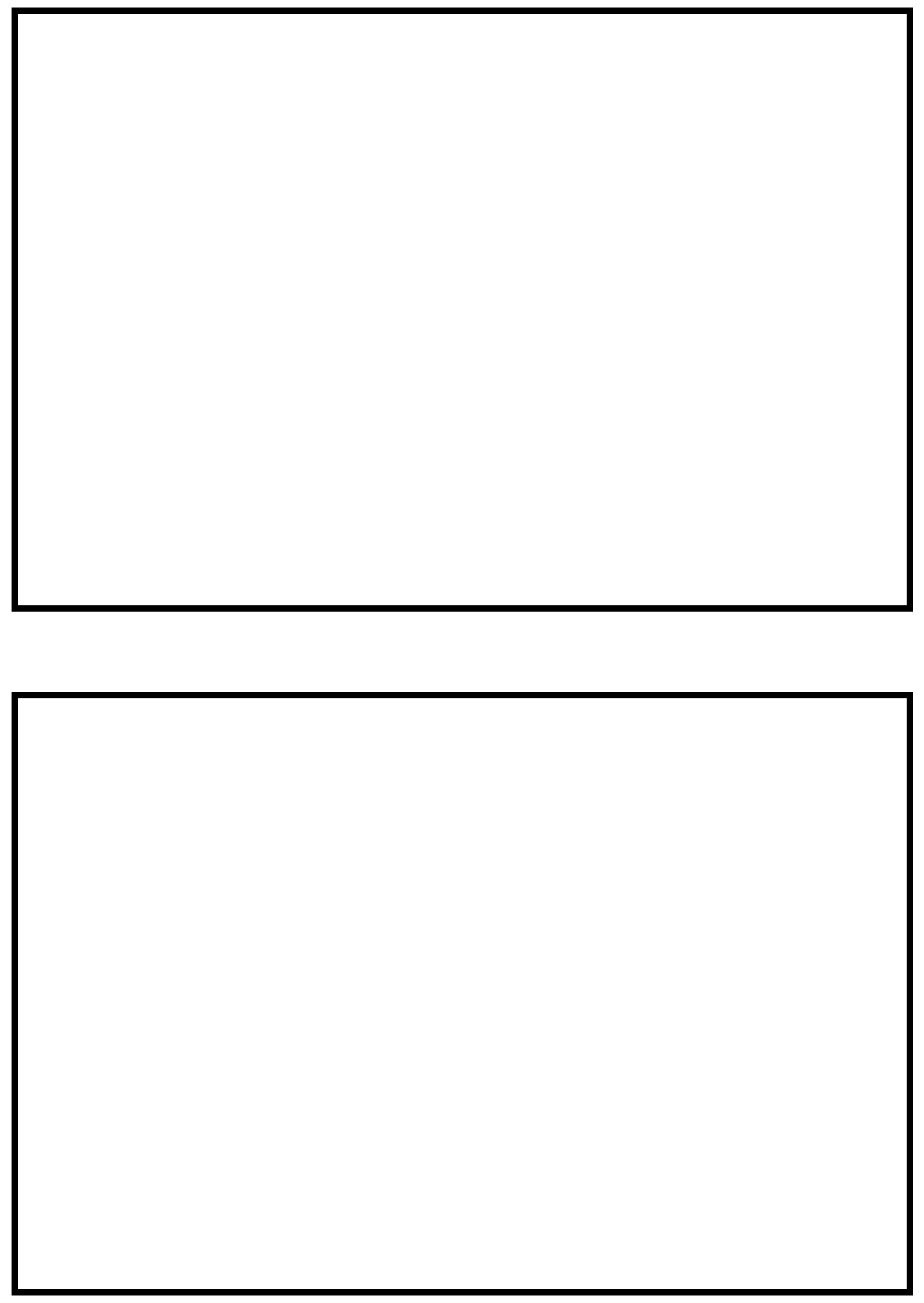

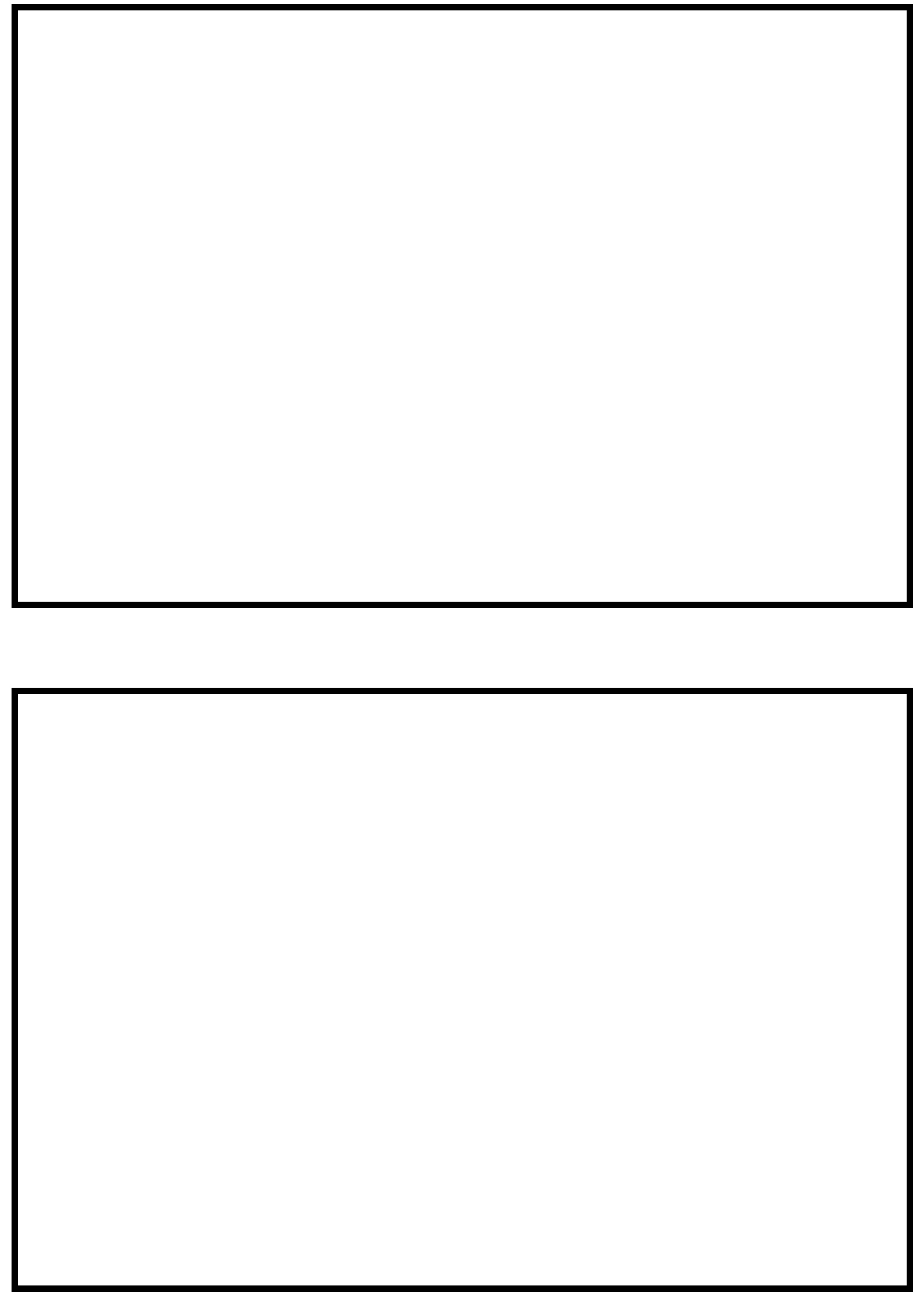


\section{LEVEL II SUMMARY}

\begin{tabular}{llllll} 
& & & \multicolumn{3}{c}{ Cobb Brook } \\
Structure Number & Stream & & & \\
County & Chittenden & Road & TH29 & District & 5
\end{tabular}

\section{Description of Bridge}

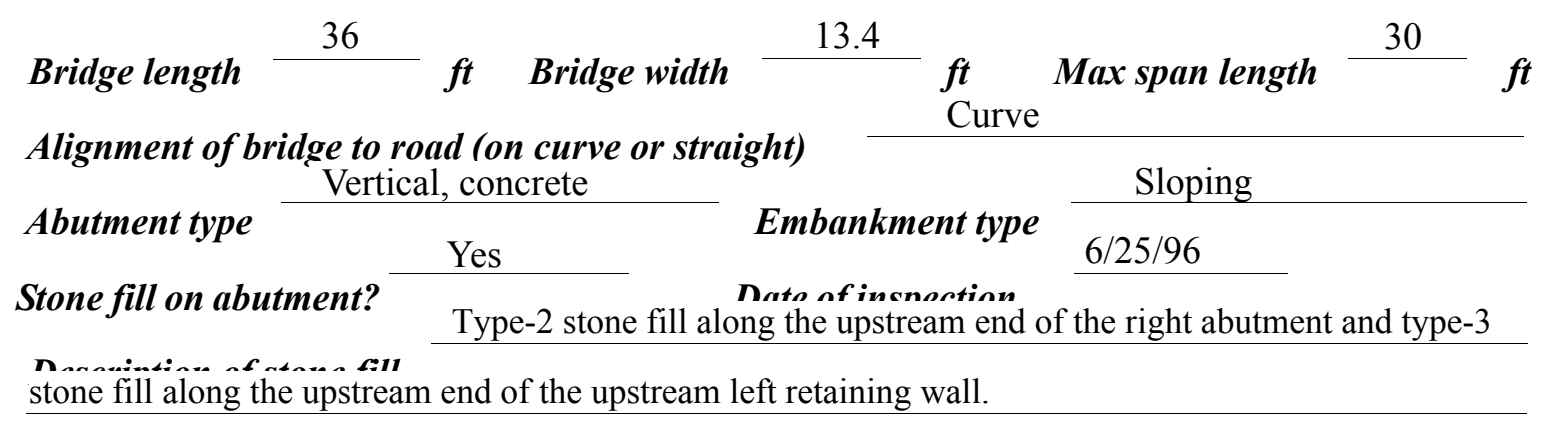

Abutments are concrete. There is a $1.5 \mathrm{ft}$ deep scour hole extending from the upstream end of the left abutment to $10 \mathrm{ft}$ under the bridge at the center of the channel and a $1.2 \mathrm{ft}$ deep scour hole along the downstream end of the right abutment.

Is bridge skewed to flood flow according to $\mathrm{No}^{\text {No survey? }}$

Debris accumulation on bridge at time of Level I or Level II site visit:

\begin{tabular}{|c|c|c|c|}
\hline & $\begin{array}{c}\text { Date of insnortion } \\
6 / 25 / 96 \\
\end{array}$ & $\begin{array}{l}\text { Percent of a channal } \\
\text { blocked inortzontatly }\end{array}$ & $\begin{array}{l}\text { Percent of } 0 \\
\text { blocked verticatty }\end{array}$ \\
\hline Level I & $6 / 25 / 96$ & 0 & 0 \\
\hline $\begin{array}{l}\text { Level II } \\
\text { banks up }\end{array}$ & \multicolumn{3}{|c|}{ Moderate. There are some trees and debris caught on boulders and } \\
\hline
\end{tabular}

Bedrock outcropping, downed trees, and boulders in the upstream and downstream channel will Doscriho anv, foaturos noar ar at tho hridoo that mav, affort flow, (includo ahsorvation dato) affect flow at lower flows. Noted 6/25/96. 


\section{Description of the Geomorphic Setting}

General topography The channel is located within a moderate relief valley setting with steep valley walls on both sides.

Geomorphic conditions at bridge site: downstream (DS), upstream (US)

Date of inspection $\quad 6 / 25 / 96$

DS left: $\quad$ Steep channel bank to a steep valley wall.

DS right: $\quad$ Steep channel bank to a narrow flood plain.

US left: $\quad$ Steep channel bank to a steep valley wall.

US right: $\quad$ Steep channel bank to a narrow flood plain.

\section{Description of the Channel}

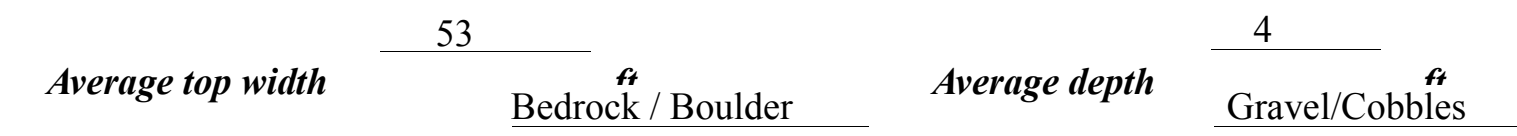

Predominant bed material

Bank material

Sinuous and straight

with non-alluvial channel boundaries and no flood plain.

$6 / 25 / 96$

Vegetative co 1 Trees and brush

DS left: $\quad$ Trees and brush

DS right: $\quad$ Trees and brush

US left: $\quad$ Trees and brush

US right: $\quad$ Y

Do banks appear stable? -

date of observatton.

The assessment of

6/25/96 noted flow conditions up to bank-full level are influenced by boulders and bedrock Describe any obstructions in channel and date of observation.

outcroppings in the upstream and downstream channel. In addition, a tree is caught on boulders

in the channel $50 \mathrm{ft}$ upstream. 


\title{
Hydrology
}

Drainage area $\quad 4.16 \boldsymbol{m i}^{2}$

Percentage of drainage area in physiographic provinces: (approximate)

Physiographic province/section

New England/Green Mountain
Percent of drainage area 100

\begin{abstract}
Is drainage area considered rural or urban?
Rural None.

urbanization:

Describe any significant
\end{abstract}

Is there a USGS gage on the stream of interest?

No

USGS gage description

USGS gage number

Gage drainage area $\mathrm{mi}^{2}$

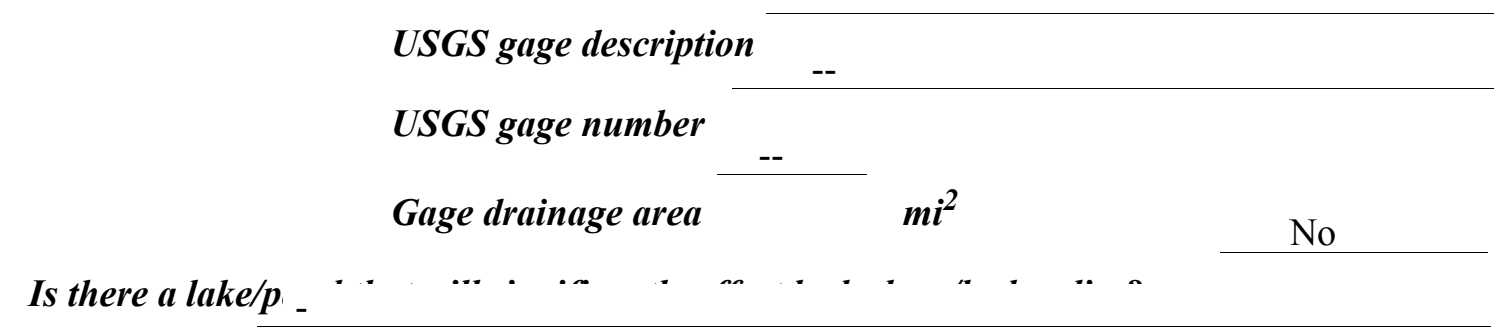

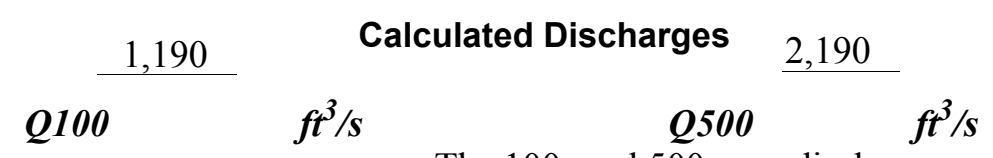

The 100- and 500-year discharges are based on a

drainage area relationship [(4.2/4.16 exp 0.67] with bridge number 7h in Huntington. Bridge number $7 \mathrm{~h}$ crosses Cobb Brook downstream of this site and has flood frequency estimates available from the VTAOT database. The drainage area above bridge number $7 \mathrm{~h}$ is 4.2 square miles (Benson, 1962; Johnson and Tasker, 1974; FHWA, 1983; Potter, 1957a\&b; Talbot, 1887). 


\section{Description of the Water-Surface Profile Model (WSPRO) Analysis}

Datum for WSPRO analysis (USGS survey, sea level, VTAOT plans)

USGS survey

Datum tie between USGS survey and VTAOT plans

None

Description of reference marks used to determine USGS datum. $\quad$ RM1 is a chiseled X on

top and $4 \mathrm{ft}$ from the upstream end of the upstream left abutment (elev. $499.16 \mathrm{ft}$, arbitrary

survey datum). RM2 is a chiseled X inside a chisled square in bedrock, $90 \mathrm{ft}$ downstream on the

left bank (elev. $492.40 \mathrm{ft}$, arbitrary survey datum).

\section{Cross-Sections Used in WSPRO Analysis}

\begin{tabular}{cccl}
\hline${ }^{1}$ Cross-section & $\begin{array}{c}\text { Section } \\
\text { Reference } \\
\text { Distance } \\
\text { (SRD) } \text { in feet }\end{array}$ & $\begin{array}{c}{ }^{2} \text { Cross-section } \\
\text { development }\end{array}$ & \multicolumn{1}{c}{ Comments } \\
\hline EXITX & -28 & 1 & Exit section \\
FULLV & 0 & 2 & $\begin{array}{l}\text { Downstream Full-valley } \\
\text { section (Templated from } \\
\text { EXITX) }\end{array}$ \\
BRIDG & 0 & 1 & $\begin{array}{l}\text { Bridge section } \\
\text { Road Grade section }\end{array}$ \\
RDWAY & 8 & 1 & $\begin{array}{l}\text { Modelled Approach sec- } \\
\text { tion (As surveyed) }\end{array}$ \\
\hline
\end{tabular}

${ }^{1}$ For location of cross-sections see plan-view sketch included with Level I field form, Appendix E. For more detail on how cross-sections were developed see WSPRO input file. 


\section{Data and Assumptions Used in WSPRO Model}

Hydraulic analyses of the reach were done by use of the Federal Highway Administration's WSPRO step-backwater computer program (Shearman and others, 1986, and Shearman, 1990). The analyses reported herein reflect conditions existing at the site at the time of the study. Furthermore, in the development of the model it was necessary to assume no accumulation of debris or ice at the site. Results of the hydraulic model are presented in the Bridge Hydraulic Summary, Appendix B, and figure 7.

Channel roughness factors (Manning's " $n$ ") used in the hydraulic model were estimated using field inspections at each cross section following the general guidelines described by Arcement and Schneider (1989). Final adjustments to the values were made during the modelling of the reach. Channel " $n$ " values for the reach ranged from 0.050 to 0.075 , and overbank "n" values were 0.060 .

Normal depth at the exit section (EXITX) was assumed as the starting water surface for the 100-year and incipient-overtopping discharges while critical depth at the exit section (EXITX) was assumed as the starting water surface for the 500 -year discharge. This depth was computed by use of the slope-conveyance method outlined in the user's manual for WSPRO (Shearman, 1990). The slope used was $0.024 \mathrm{ft} / \mathrm{ft}$ which was estimated from the topographic map (U.S. Geological Survey, 1948). This slope resulted in a normal depth $0.13 \mathrm{ft}$ less than critical depth for the 500-year discharge and WSPRO defaulted to critical depth. Critical depth in the downstream reach for the 500-year discharge is considered to be a satisfactory solution.

The surveyed approach section (APPRO) was located one bridge length upstream of the upstream face as recommended by Shearman and others (1986). This location also provides a consistent method for determining scour variables. 


\section{Bridge Hydraulics Summary}

$\begin{array}{lll}\text { Average bridge embankment elevation } & 501.3 \\ \text { Average low steel elevation } & 498.7 & \boldsymbol{f t}\end{array}$

100-year discharge $\quad 1,190 \quad \mathrm{ft}^{3} / \mathrm{s}$

Water-surface elevation in bridge opening $\quad 496.1 \quad f t$

Road overtopping? ___ Y Discharge over road __ 50 $\mathrm{ft}^{3} / \mathrm{s}$

Area of flow in bridge opening $\quad 109 \quad \mathrm{ft}^{2}$

Average velocity in bridge opening $10.4 \mathrm{ft} / \mathrm{s}$

Maximum WSPRO tube velocity at bridge $\quad 12.9 \mathrm{ft} / \mathrm{s}$

Water-surface elevation at Approach section with bridge 498.2

Water-surface elevation at Approach section without bridge $\quad 497.6$

Amount of backwater caused by bridge $\quad 0.6 \quad$ it

500-year discharge $\quad 2,190 \quad \mathrm{ft}^{3} / \mathrm{s}$

Water-surface elevation in bridge opening

$498.9 \boldsymbol{f t}$

Road overtopping? ___ Y Discharge over road __ $\quad 901 \quad \mathrm{ft}^{3} / \mathrm{s}$

Area of flow in bridge opening $\quad 175 \quad \mathrm{ft}^{2}$

Average velocity in bridge opening $7.3 \mathrm{ft} / \mathrm{s}$

Maximum WSPRO tube velocity at bridge 8.6 _s

Water-surface elevation at Approach section with bridge $\quad 500.0$

Water-surface elevation at Approach section without bridge $\quad 499.0$

Amount of backwater caused by bridge $\quad 1.0, t$

Incipient overtopping discharge $\quad 1,080 \mathrm{ft}^{3} / \mathrm{s}$

Water-surface elevation in bridge opening $495.8 \quad t$

Area of flow in bridge opening $\quad 102 \quad \mathrm{ft}^{2}$

Average velocity in bridge opening $\quad 10.6 \quad \mathrm{ft} / \mathrm{s}$

Maximum WSPRO tube velocity at bridge $13.0 \mathrm{ft} / \mathrm{s}$

Water-surface elevation at Approach section with bridge

Water-surface elevation at Approach section without bridge

Amount of backwater caused by bridge $\quad 0.8$ it

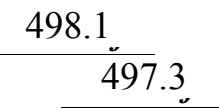




\section{Scour Analysis Summary}

\section{Special Conditions or Assumptions Made in Scour Analysis}

Scour depths were computed using the general guidelines described in Hydraulic Engineering Circular 18 (Richardson and others, 1995). Scour depths were calculated assuming an infinite depth of erosive material and a homogeneous particle-size distribution. The results of the scour analysis are presented in tables 1 and 2 and a graph of the scour depths is presented in figure 8 .

Contraction scour for the 100-year and incipient roadway-overtopping discharges were computed by use of the Laursen clear-water contraction scour equation (Richardson and others, 1995, p. 32, equation 20). At this site, the 500-year discharge resulted in unsubmerged orifice flow. Contraction scour at bridges with orifice flow is best estimated by use of the Chang pressure-flow scour equation (oral communication, J. Sterling Jones, October 4, 1996). Thus, contraction scour for this discharge was computed by use of the Chang equation (Richardson and others, 1995, p. 145-146).

For the 500-year discharge, which resulted in orifice flow, estimates of contraction scour were also computed by use of the Laursen clear-water contraction scour equation and the Umbrell pressure-flow equation (Richardson and others, 1995, p. 144) and presented in Appendix F. Furthermore, since the 500-year discharge resulted in unsubmerged orifice flow, contraction scour was computed by substituting an estimate for the depth of flow at the downstream bridge face in the contraction scour equations. Results with respect to this substitution is provided in Appendix F.

Abutment scour was computed by use of the Froehlich equation (Richardson and others, 1995, p. 48, equation 28). Variables for the Froehlich equation include the Froude number of the flow approaching the embankments, the length of the embankment blocking flow, and the depth of flow approaching the embankment less any roadway overtopping. 


\section{Scour Results}

\section{0-yr discharge 500-yr discharge}

Contraction scour:

(Scour depths in feet)

Main channel

Live-bed scour

Clear-water scour

Depth to armoring

Left overbank

Right overbank

Local scour:

Abutment scour

12.5

9.9

6.2

Left abutment

8.6-

8.4-

Right abutment

Pier scour

Pier 1

Pier 2

$$
8.61 .0^{-}
$$

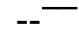

$--$

$10.4^{-}$ overtopping discharge

Incipient
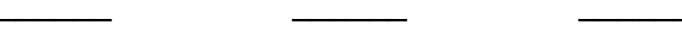

Pier 3

\section{Riprap Sizing}

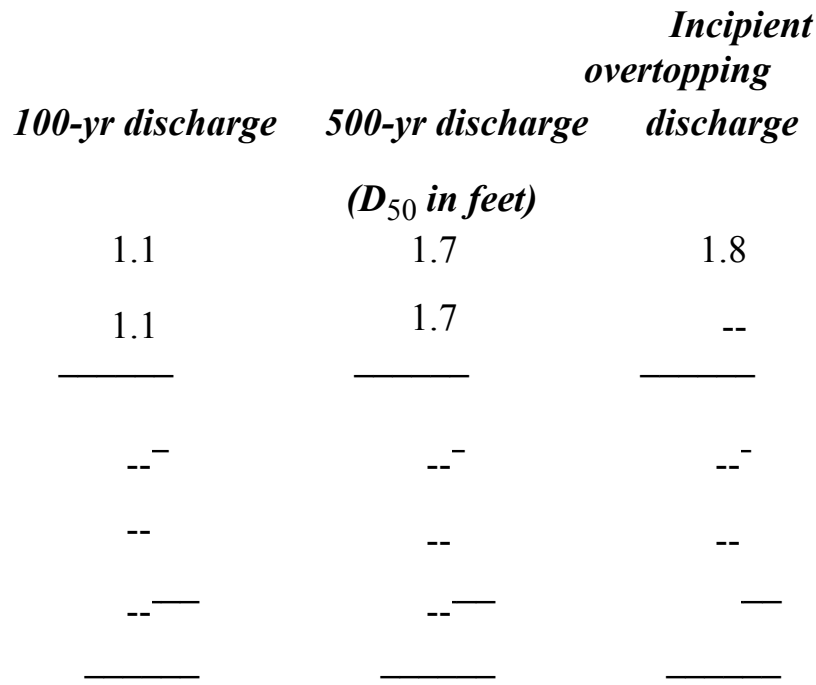




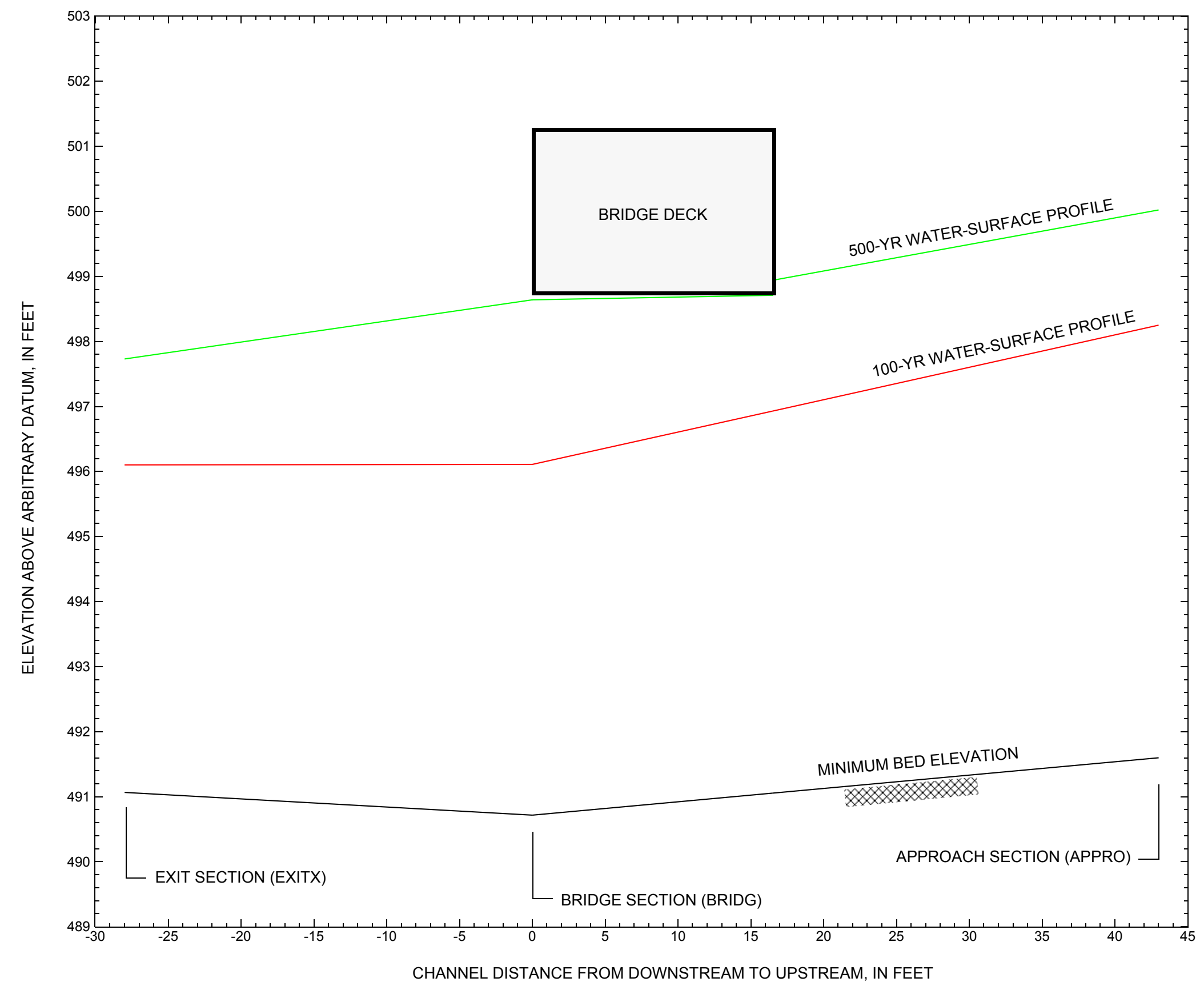

Figure 7. Water-surface profiles for the 100- and 500-yr discharges at structure HUNTTH00290029 on Town Highway 29, crossing Cobb Brook, Huntington, Vermont. 


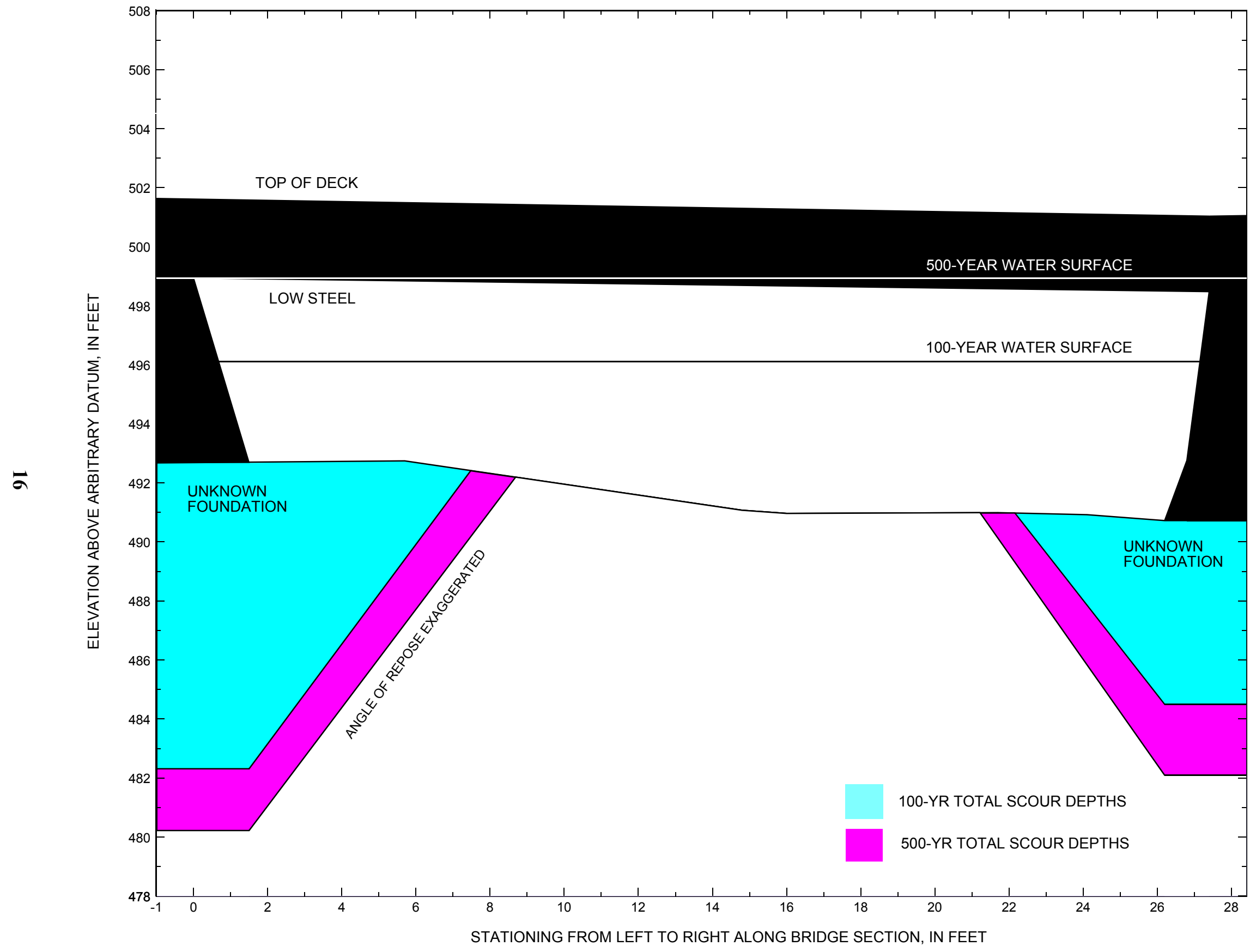

Figure 8. Scour elevations for the 100-yr and 500-yr discharges at structure HUNTTH00290029 on Town Highway 29, crossing Cobb Brook, Huntington, Vermont. 
Table 1. Remaining footing/pile depth at abutments for the 100-year discharge at structure HUNTTH00290029 on Town Highway 29, crossing Cobb Brook, Huntington, Vermont.

[VTAOT, Vermont Agency of Transportation; --,no data]

\begin{tabular}{|c|c|c|c|c|c|c|c|c|c|c|c|}
\hline Description & Station $^{1}$ & $\begin{array}{l}\text { VTAOT } \\
\text { minimum } \\
\text { low-chord } \\
\text { elevation } \\
\text { (feet) }\end{array}$ & $\begin{array}{l}\text { Surveyed } \\
\text { minimum } \\
\text { low-chord } \\
\text { elevation } \\
\text { (feet) }\end{array}$ & $\begin{array}{c}\text { Bottom of } \\
\text { footing/pile } \\
\text { elevation }{ }^{2} \\
\text { (feet) }\end{array}$ & $\begin{array}{l}\text { Channel } \\
\text { elevation at } \\
\text { abutment/ } \\
\text { pier }^{2} \\
\text { (feet) }\end{array}$ & $\begin{array}{l}\text { Contraction } \\
\text { scour depth } \\
\text { (feet) }\end{array}$ & $\begin{array}{l}\text { Abutment } \\
\text { scour } \\
\text { depth } \\
\text { (feet) }\end{array}$ & $\begin{array}{l}\text { Pier } \\
\text { scour } \\
\text { depth } \\
\text { (feet) }\end{array}$ & $\begin{array}{l}\text { Depth of } \\
\text { total scour } \\
\text { (feet) }\end{array}$ & $\begin{array}{c}\text { Elevation of } \\
\text { scour }^{2} \\
\text { (feet) }\end{array}$ & $\begin{array}{c}\text { Remaining } \\
\text { footing/pile } \\
\text { depth } \\
\text { (feet) }\end{array}$ \\
\hline \multicolumn{12}{|c|}{100 -yr. discharge is 1,190 cubic-feet per second } \\
\hline Left abutment & 1.5 & -- & 498.9 & -- & 492.7 & 0.0 & 10.4 & -- & 10.4 & 482.3 & -- \\
\hline Right abutment & 26.2 & -- & 498.5 & -- & 490.7 & 0.0 & 6.2 & -- & 6.2 & 484.5 & -- \\
\hline
\end{tabular}

1.Measured along the face of the most constricting side of the bridge.

2.Arbitrary datum for this study.

Table 2. Remaining footing/pile depth at abutments for the 500-year discharge at structure HUNTTH00290029 on Town Highway 29, crossing Cobb Brook, Huntington, Vermont.

[VTAOT, Vermont Agency of Transportation; --, no data]

\begin{tabular}{|c|c|c|c|c|c|c|c|c|c|c|c|}
\hline Description & Station $^{1}$ & $\begin{array}{l}\text { VTAOT } \\
\text { minimum } \\
\text { low-chord } \\
\text { elevation } \\
\text { (feet) }\end{array}$ & $\begin{array}{c}\text { Surveyed } \\
\text { minimum } \\
\text { low-chord } \\
\text { elevation } \\
\text { (feet) }\end{array}$ & $\begin{array}{c}\text { Bottom of } \\
\text { footing/pile } \\
\text { elevation } \\
\text { (feet) }\end{array}$ & $\begin{array}{c}\text { Channel } \\
\text { elevation at } \\
\text { abutment/ } \\
\text { pier }^{2} \\
\text { (feet) }\end{array}$ & $\begin{array}{l}\text { Contraction } \\
\text { scour depth } \\
\text { (feet) }\end{array}$ & $\begin{array}{c}\text { Abutment } \\
\text { scour } \\
\text { depth } \\
\text { (feet) }\end{array}$ & $\begin{array}{l}\text { Pier } \\
\text { scour } \\
\text { depth } \\
\text { (feet) }\end{array}$ & $\begin{array}{l}\text { Depth of } \\
\text { total scour } \\
\text { (feet) }\end{array}$ & $\begin{array}{c}\text { Elevation of } \\
\text { scour }^{2} \\
\text { (feet) }\end{array}$ & $\begin{array}{c}\text { Remaining } \\
\text { footing/pile } \\
\text { depth } \\
\text { (feet) }\end{array}$ \\
\hline \multicolumn{12}{|c|}{500 -yr. discharge is 2,190 cubic-feet per second } \\
\hline Left abutment & 1.5 & -- & 498.9 & -- & 492.7 & 0.0 & 12.5 & -- & 12.5 & 480.2 & -- \\
\hline Right abutment & 26.2 & -- & 498.5 & -- & 490.7 & 0.0 & 8.6 & -- & 8.6 & 482.1 & -- \\
\hline
\end{tabular}

1.Measured along the face of the most constricting side of the bridge.

2.Arbitrary datum for this study. 


\section{SELECTED REFERENCES}

Arcement, G.J., Jr., and Schneider, V.R., 1989, Guide for selecting Manning's roughness coefficients for natural channels and flood plains:

U.S. Geological Survey Water-Supply Paper 2339, 38 p.

Barnes, H.H., Jr., 1967, Roughness characteristics of natural channels: U.S. Geological Survey Water-Supply Paper 1849,213 p.

Benson, M. A., 1962, Factors Influencing the Occurrence of Floods in a Humid Region of Diverse Terrain: U.S. Geological Survey WaterSupply Paper 1580-B, 64 p.

Brown, S.A. and Clyde, E.S., 1989, Design of riprap revetment: Federal Highway Administration Hydraulic Engineering Circular No. 11, Publication FHWA-IP-89-016, $156 \mathrm{p}$

Federal Emergency Management Agency, 1978, Flood Insurance Study, Town of Huntington, Chittenden County, Vermont: Washington, D.C., January 1978.

Federal Highway Administration, 1983, Runoff estimates for small watersheds and development of sound design: Federal Highway Administration Report FHWA-RD-77-158.

Federal Highway Administration, 1993, Stream Stability and Scour at Highway Bridges: Participant Workbook: Federal Highway Administration Report FHWA-HI-91-011.

Froehlich, D.C., 1989, Local scour at bridge abutments in Ports, M.A., ed., Hydraulic Engineering--Proceedings of the 1989 National Conference on Hydraulic Engineering: New York, American Society of Civil Engineers, p. 13-18.

Hayes, D.C.,1993, Site selection and collection of bridge-scour data in Delaware, Maryland, and Virginia: U.S. Geological Survey WaterResources Investigation Report 93-4017, 23 p.

Interagency Advisory Committee on Water Data, 1982, Guidelines for determining flood flow frequency: U.S. Geological Survey, Bulletin 17B of the Hydrology Subcommittee, 190 p.

Johnson, C.G. and Tasker, G.D.,1974, Progress report on flood magnitude and frequency of Vermont streams: U.S. Geological Survey OpenFile Report 74-130, 37 p.

Lagasse, P.F., Schall, J.D., Johnson, F., Richardson, E.V., Chang, F., 1995, Stream Stability at Highway Structures: Federal Highway Administration Hydraulic Engineering Circular No. 20, Publication FHWA-IP-90-014, 144 p.

Laursen, E.M., 1960, Scour at bridge crossings: Journal of the Hydraulics Division, American Society of Civil Engineers, v. 86, no. HY2, p. 39-53.

Potter, W. D., 1957a, Peak rates of runoff in the Adirondack, White Mountains, and Maine woods area, Bureau of Public Roads

Potter, W. D., 1957b, Peak rates of runoff in the New England Hill and Lowland area, Bureau of Public Roads

Richardson, E.V. and Davis, S.R., 1995, Evaluating scour at bridges: Federal Highway Administration Hydraulic Engineering Circular No. 18, Publication FHWA-IP-90-017, 204 p.

Richardson, E.V., Simons, D.B., and Julien, P.Y., 1990, Highways in the river environment: Federal Highway Administration Publication FHWA-HI-90-016.

Ritter, D.F., 1984, Process Geomorphology: W.C. Brown Co., Debuque, Iowa, 603 p.

Shearman, J.O., 1990, User's manual for WSPRO--a computer model for water surface profile computations: Federal Highway Administration Publication FHWA-IP-89-027, 187 p.

Shearman, J.O., Kirby, W.H., Schneider, V.R., and Flippo, H.N., 1986, Bridge waterways analysis model; research report: Federal Highway Administration Publication FHWA-RD-86-108, 112 p.

Talbot, A.N., 1887, The determination of water-way for bridges and culverts.

U.S. Department of Transportation, 1993, Stream stability and scour at highway bridges, Participant Workbook: Federal Highway Administration Publication FHWA HI-91-011.

U.S. Geological Survey, 1948, Huntington, Vermont 7.5 Minute Series quadrangle map: U.S. Geological Survey Topographic Maps, Photorevised 1980, Scale 1:24,000. 


\section{APPENDIX A: \\ WSPRO INPUT FILE}




\section{WSPRO INPUT FILE (continued)}

SK

$\mathrm{XS}$

GR

GR

GR

GR

GR

$\mathrm{N}$

SA

*

$\mathrm{X}$

*

BR

GR

GR

GR

*

$\mathrm{CD}$

$\mathrm{N}$

*

*

$\mathrm{XR}$

GR

GR

GR

*

AS

GR

GR

GR

GR

*

$\mathrm{N}$

SA

HP 1 BRIDG

HP 2 BRIDG

HP 2 RDWAY

$\mathrm{HP} 1 \mathrm{APPRO}$

HP 2 APPRO

*

HP 1 BRIDG

HP 2 BRIDG

HP 1 BRIDG

HP 2 RDWAY

HP 1 APPRO

HP 2 APPRO
U.S. Geological Survey WSPRO Input File hunt029.wsp

Hydraulic analysis for structure HUNTTH00290029 Date: 02-JUN-97

Bridge \#29 over Cobb Brook in Huntington, Vt. RHF

$62930552553551516 \quad 17 \quad 13 \quad 3 * \begin{array}{llllllllll}15 & 14 & 23 & 21 & 11 & 12 & 4 & 7 & 3\end{array}$

$1190.0 \quad 2190.0 \quad 1080.0$

$0.024 \quad 0.024 \quad 0.024$

$-28$

$-72.4,509.21$

$-1.2,492.60$

$18.6,491.66$

$-21.2, \quad 500.36$

$0.0,492.30$

$-16.0,498.27$

$-6.2,494.66$

$26.6,491.07$

$9.2,492.28$

$30.5,491.61$

$83.4,497.01$

$37.7,497.50$

$60.8,497.20$

$209.2, \quad 504.77$

0.060

0.070

0.060

$-21.2$

37.7

FULLV

0

* * *

0.004

SRD LSEL XSSKEW

$\begin{array}{ll}498.71 & 20.0\end{array}$

$0.0,498.94 \quad 1.5,492.67$

$16.0,490.96 \quad 21.7,490.99$

$26.8,492.77$

$27.4,498.48$

$5.7,492.74$

$14.8,491.07$

$24.1,490.92$

$0.0,498.94$

$26.2,490.72$

BRTYPE BRWDTH

116.5

0.050

SRD EMBWID IPAVE

$\begin{array}{rr}8 & 13 . \\ -126.8, & 514.45\end{array}$

$29.1,501.03$

$99.0,497.92$

$-77.9,508.02$

$-34.2,502.67$

$0.0,501.61$

$46.8,499.80$

$66.2,498.02$

$87.5,497.39$

$142.8,498.21$

$209.2, \quad 504.77$

$-16.9,500.07$

$19.1,491.60$

$-10.5,494.45$

$24.4,492.04$

$81.5,499.11$

$100.7,498.70$

$30.2,496.24$

$159.2,503.27$

$176.2,506.33$

0.060

$-16.9$

0.075

30.2

0.060

496.121496 .12

496.12 * * 1140

498.20 *

498.231498 .23

498.23 * 1190

498.941498 .94

498.94 * 1269

498.641498 .64

499.70 * * 901

500.021500 .02

500.02 * $* 2190$ 


\section{APPENDIX B: \\ WSPRO OUTPUT FILE}




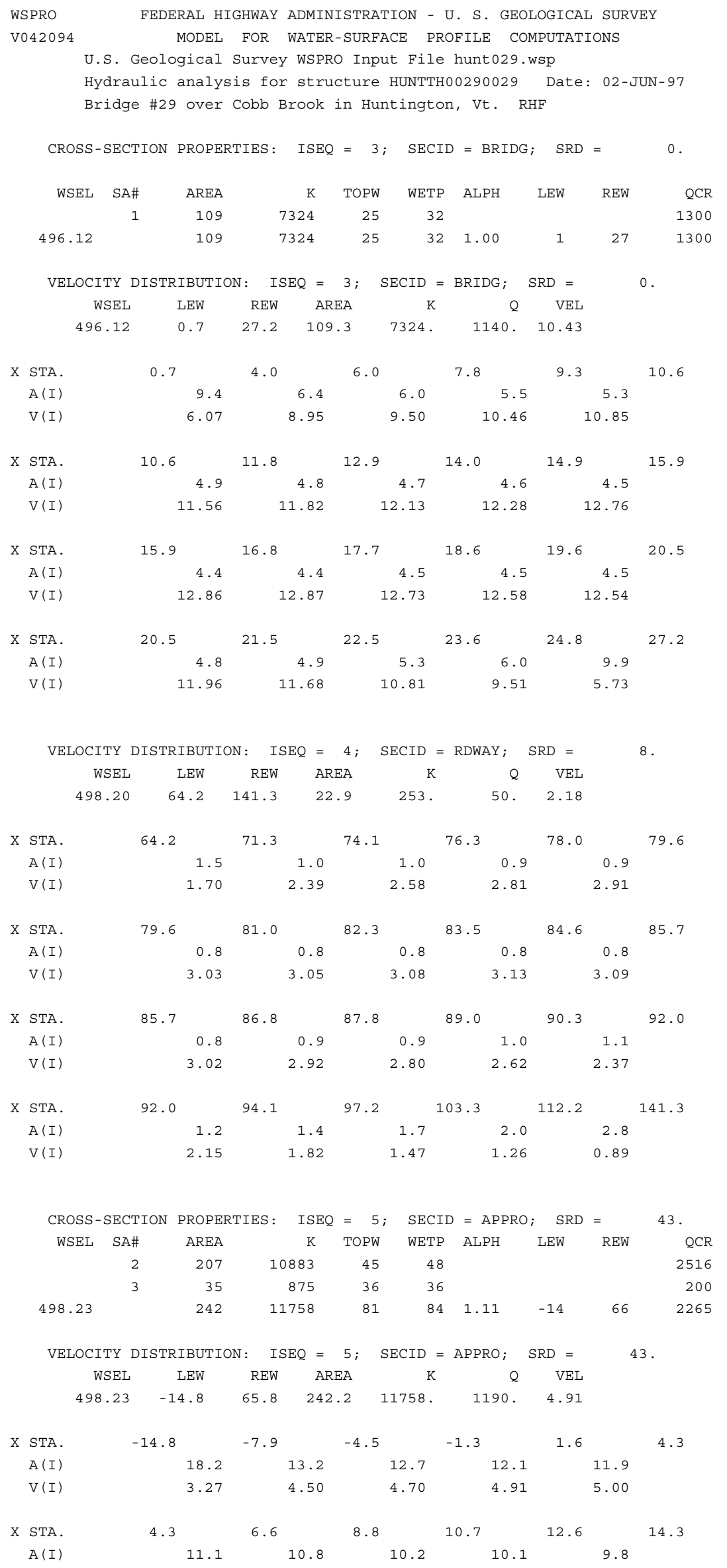


WSPRO OUTPUT FILE (continued)

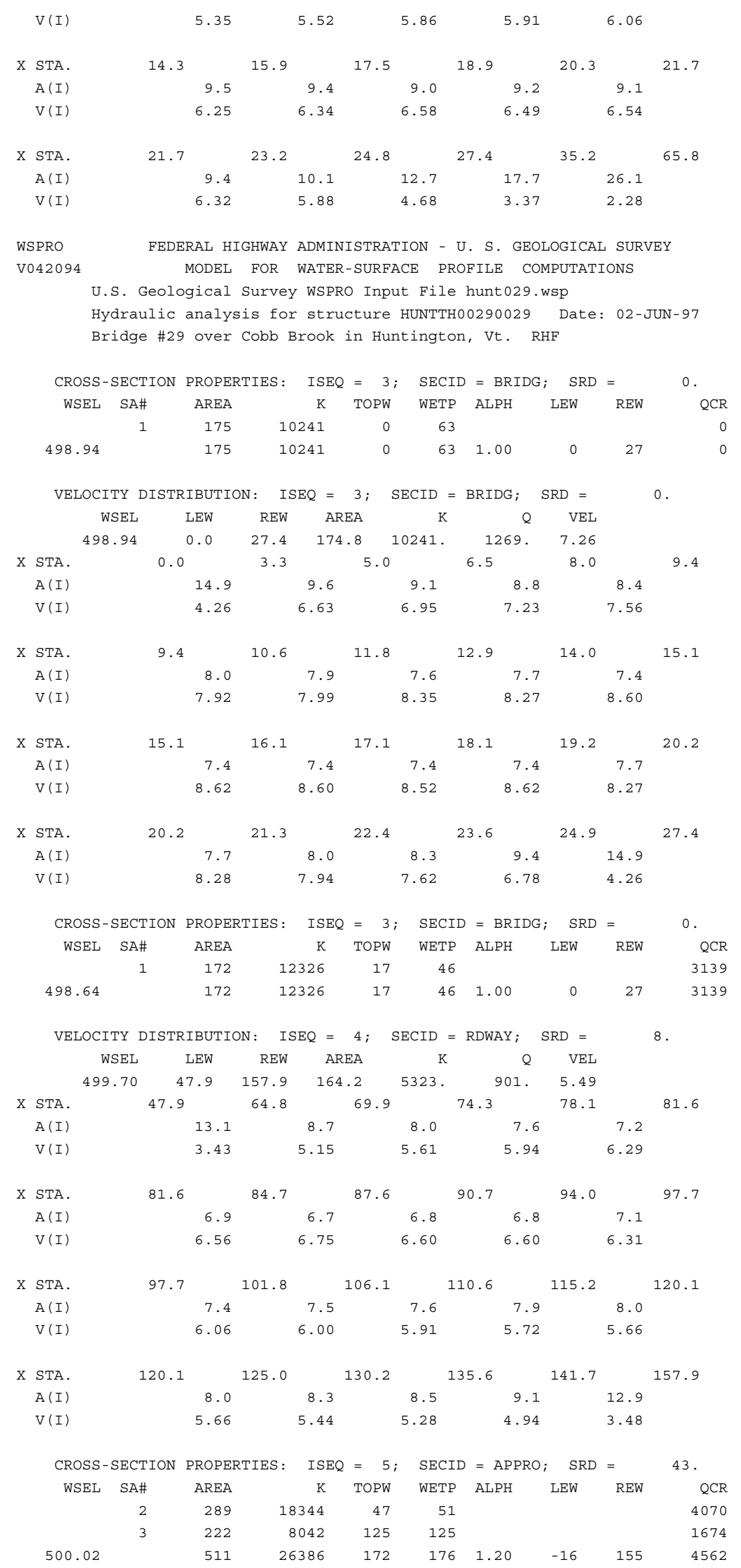




\section{WSPRO OUTPUT FILE (continued)}

VELOCITY DISTRIBUTION: ISEQ $=5 ;$ SECID $=$ APPRO; $\quad$ SRD $=\quad 43$.

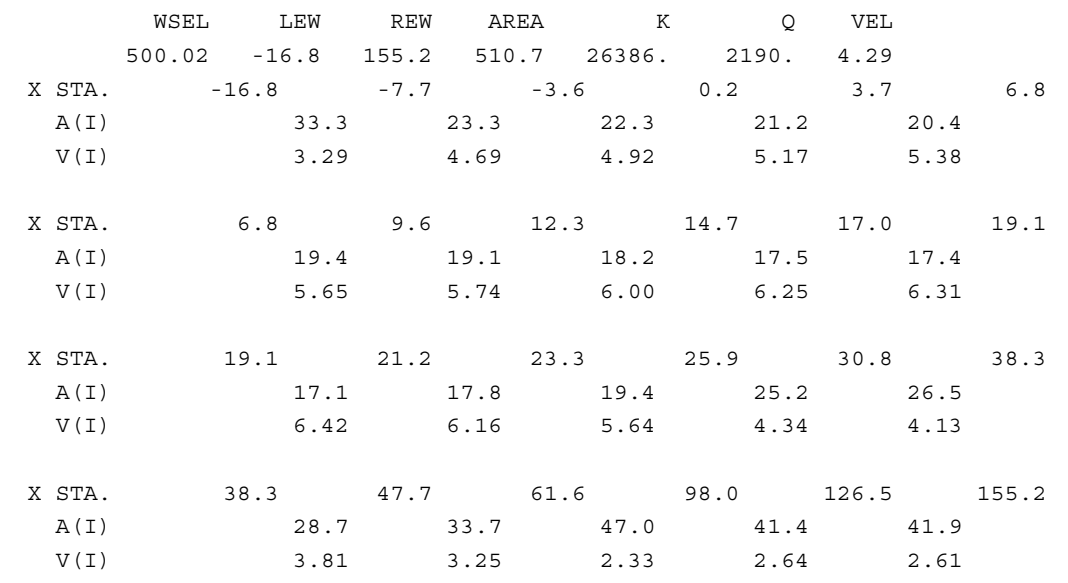

U.S. Geological Survey WSPRO Input File hunt029.wsp

Hydraulic analysis for structure HUNTTH00290029 Date: 02-JUN-97

Bridge \#29 over Cobb Brook in Huntington, Vt. RHF

\begin{tabular}{|c|c|c|c|c|c|c|c|c|c|c|c|}
\hline & CROSS-SEC & CTION & PROPER & PIES : & ISEQ & $=3 ;$ & SECII & $=$ BRIDG; & SRD & $=$ & 0 . \\
\hline & WSEL & SA\# & AREA & & $\mathrm{K}$ & TOPW & WETP & $\mathrm{ALPH}$ & LEW & REW & QCR \\
\hline & & 1 & 102 & & 6594 & 25 & 32 & & & & 1172 \\
\hline & 495.82 & & 102 & & 6594 & 25 & 32 & 1.00 & 1 & 27 & 1172 \\
\hline & VELOCITY & I DISTR & RIBUTIOI & & $\mathrm{SEQ}=$ & $3 ;$ & $E C I D=$ & BRIDG ; & $\mathrm{SRD}=$ & & 0 . \\
\hline & WSEI & & LEW & REW & $\mathrm{ARE}$ & & K & Q & VEL & & \\
\hline & 495.82 & & 0.7 & 27.1 & 101. & & 6594. & 1080. & 10.60 & & \\
\hline X & STA. & 0.7 & & 4.1 & & 6.1 & & 7.9 & 9.4 & & 10.8 \\
\hline & $A(I)$ & & 8.7 & & 6.0 & & 5.5 & 5.2 & & 4.9 & \\
\hline & $V(I)$ & & 6.19 & & 9.04 & & 9.74 & 10.43 & & 11.05 & \\
\hline $\mathrm{X}$ & STA. & 10.8 & & 12.0 & & 13.1 & & 4.1 & 15.1 & & 16.0 \\
\hline & $A(I)$ & & 4.8 & & 4.5 & & 4.4 & 4.3 & & 4.2 & \\
\hline & $V(I)$ & & 11.33 & & 12.06 & & 2.35 & 12.49 & & 13.00 & \\
\hline $\mathrm{X}$ & STA. & 16.0 & & 16.9 & & 17.8 & & 8.8 & 19.7 & & 20.6 \\
\hline & $A(I)$ & & 4.2 & & 4.1 & & 4.2 & 4.2 & & 4.3 & \\
\hline & $V(I)$ & & 13.00 & & 13.02 & & 2.88 & 12.99 & & 12.45 & \\
\hline X & STA. & 20.6 & & 21.6 & & 22.6 & & 23.7 & 24.9 & & 27.1 \\
\hline & $A(I)$ & & 4.3 & & 4.5 & & 4.9 & 5.6 & & 9.1 & \\
\hline & $V(I)$ & & 12.44 & & 11.87 & & 0.98 & 9.66 & & 5.95 & \\
\hline
\end{tabular}

CROSS-SECTION PROPERTIES: ISEQ $=5 ;$ SECID $=$ APPRO; $\quad$ SRD $=43$.

$\begin{array}{rrrrrrrrrr}\text { WSEL } & \text { SA\# } & \text { AREA } & \text { K } & \text { TOPW } & \text { WETP } & \text { ALPH } & \text { LEW } & \text { REW } & \text { QCR } \\ & 2 & 200 & 10331 & 45 & 48 & & & & 2399 \\ 498.08 & 3 & 30 & 710 & 33 & 33 & & & & 165 \\ & & 230 & 11041 & 78 & 81 & 1.10 & -14 & 63 & 2145\end{array}$

VELOCITY DISTRIBUTION: ISEQ $=5 ;$ SECID $=$ APPRO; $\quad$ SRD $=43$.

$\begin{array}{rrrrrrr}\text { WSEL } & \text { LEW } & \text { REW } & \text { AREA } & \text { K } & \text { Q } & \text { VEL } \\ 498.08 & -14.6 & 63.1 & 230.4 & 11041 . & 1080 . & 4.69\end{array}$

\begin{tabular}{|c|c|c|c|c|c|c|c|}
\hline $\mathrm{X}$ & STA. & -14.6 & -7.9 & -4.4 & -1.3 & 1.7 & 4.3 \\
\hline & $A(I)$ & 17.2 & 13.0 & 12.1 & 11.8 & 11.1 & \\
\hline & $V(I)$ & 3.14 & 4.16 & 4.47 & 4.56 & 4.85 & \\
\hline$x$ & STA. & 4.3 & 6.6 & 8.8 & 10.7 & 12.5 & 14.2 \\
\hline & $A(I)$ & 10.7 & 10.4 & 9.8 & 9.7 & 9.5 & \\
\hline & $V(I)$ & 5.06 & 5.21 & 5.53 & 5.57 & 5.71 & \\
\hline $\mathrm{X}$ & STA. & 14.2 & 15.8 & 17.3 & 18.7 & 20.1 & 21.4 \\
\hline
\end{tabular}


WSPRO OUTPUT FILE (continued)

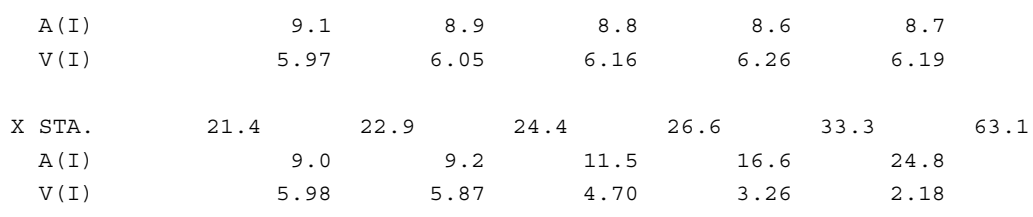

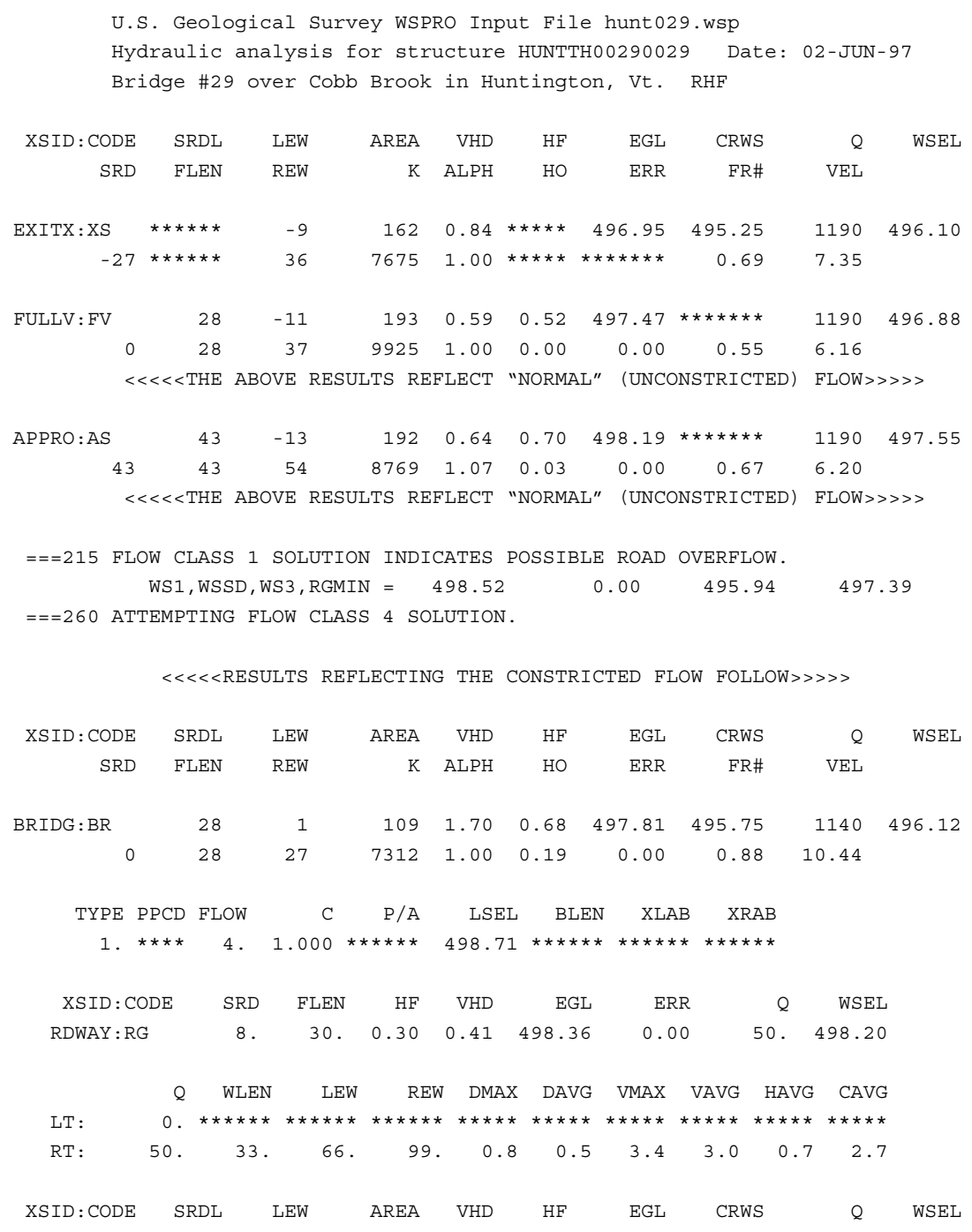


WSPRO OUTPUT FILE (continued)

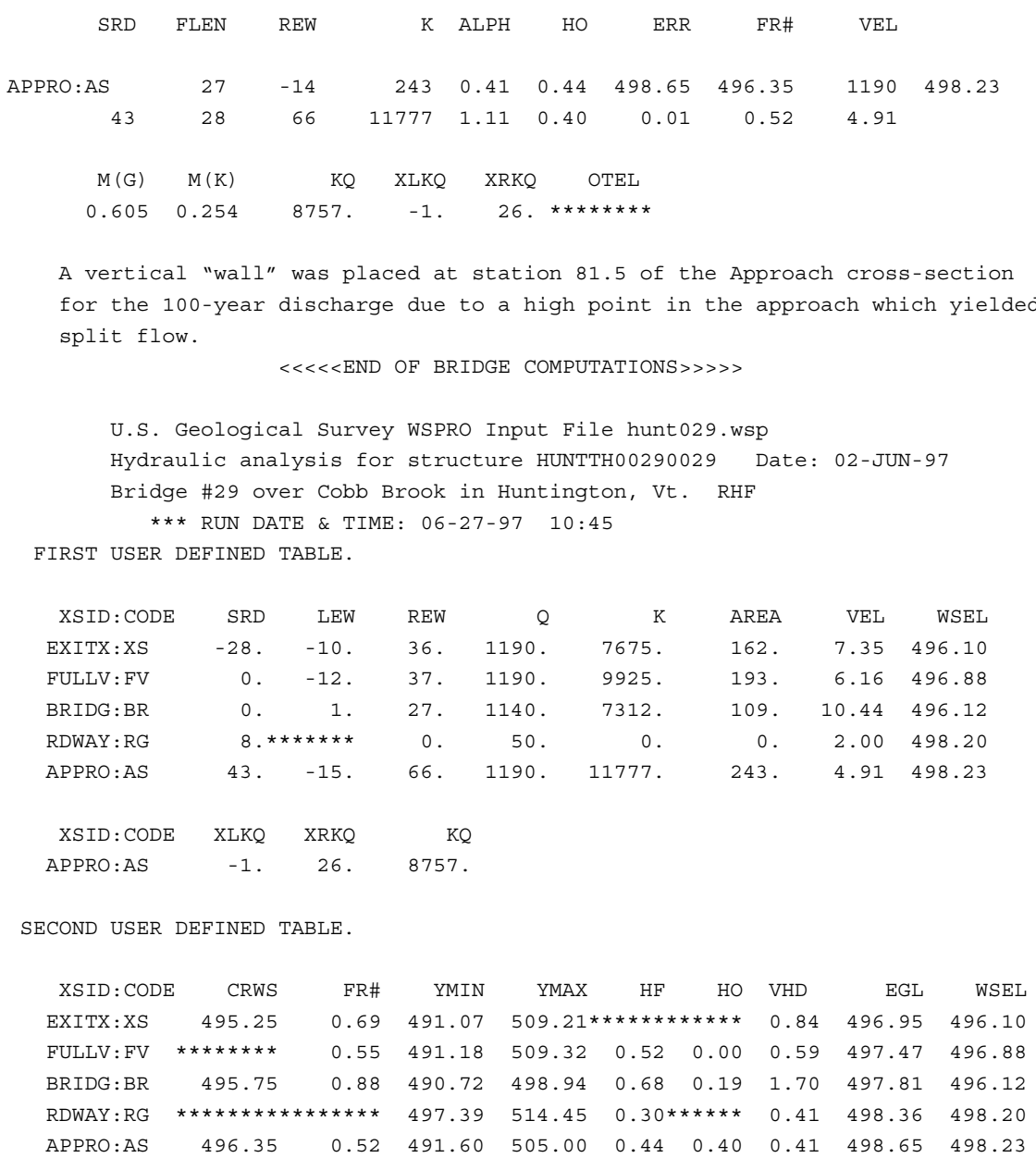

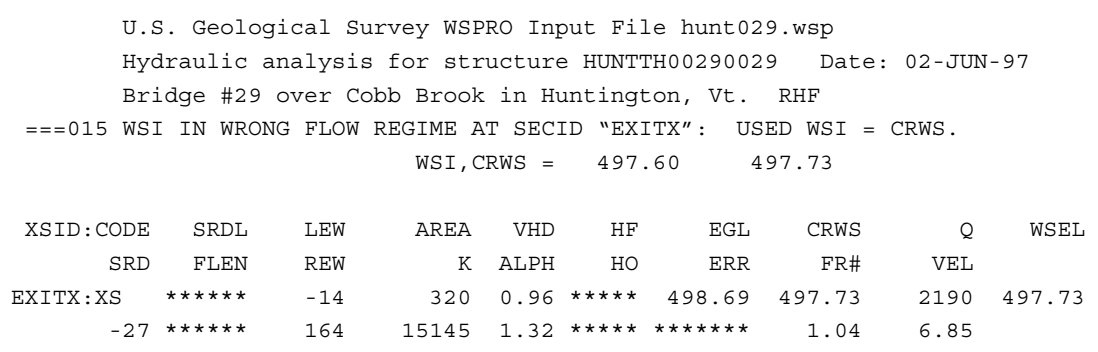

$==135$ CONVEYANCE RATIO OUTSIDE OF RECOMMENDED LIMITS.

"FULLV" KRATIO $=1.52$

$\begin{array}{rrrrrrrrrr}\text { FULLV : FV } & 28 & -16 & 465 & 0.44 & 0.38 & 499.07 & * \star * \star * * * & 2190 & 498.64 \\ & 0 & 28 & 169 & 23059 & 1.27 & 0.00 & 0.00 & 0.59 & 4.71\end{array}$

<<<< THE ABOVE RESULTS REFLECT "NORMAL" (UNCONSTRICTED) FLOW $>>>>$

$===125$ FR\# EXCEEDS FNTEST AT SECID "APPRO": TRIALS CONTINUED.

FNTEST, FR\#, WSEL, CRWS $=\begin{array}{llll}0.80 & 0.90 & 498.99 & 498.06\end{array}$

$===110$ WSEL NOT FOUND AT SECID "APPRO": REDUCED DELTAY.

$$
\text { WSLIM1, WSLIM2, DELTAY }=498.14 \quad 506.33 \quad 0.50
$$

$==115$ WSEL NOT FOUND AT SECID "APPRO": USED WSMIN = CRWS.

WSLIM1,WSLIM2, CRWS $=498.14 \quad 506.33 \quad 498.06$

$===135$ CONVEYANCE RATIO OUTSIDE OF RECOMMENDED LIMITS.

$$
\text { "APPRO" KRATIO }=0.69
$$

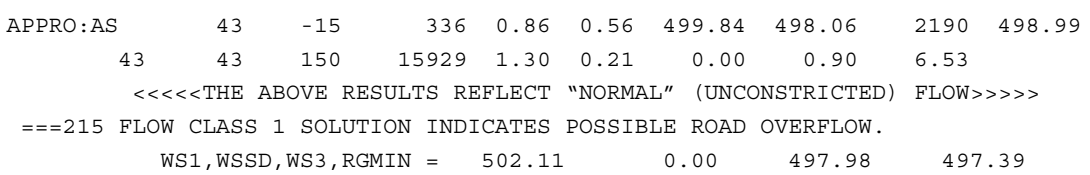


WSPRO OUTPUT FILE (continued)

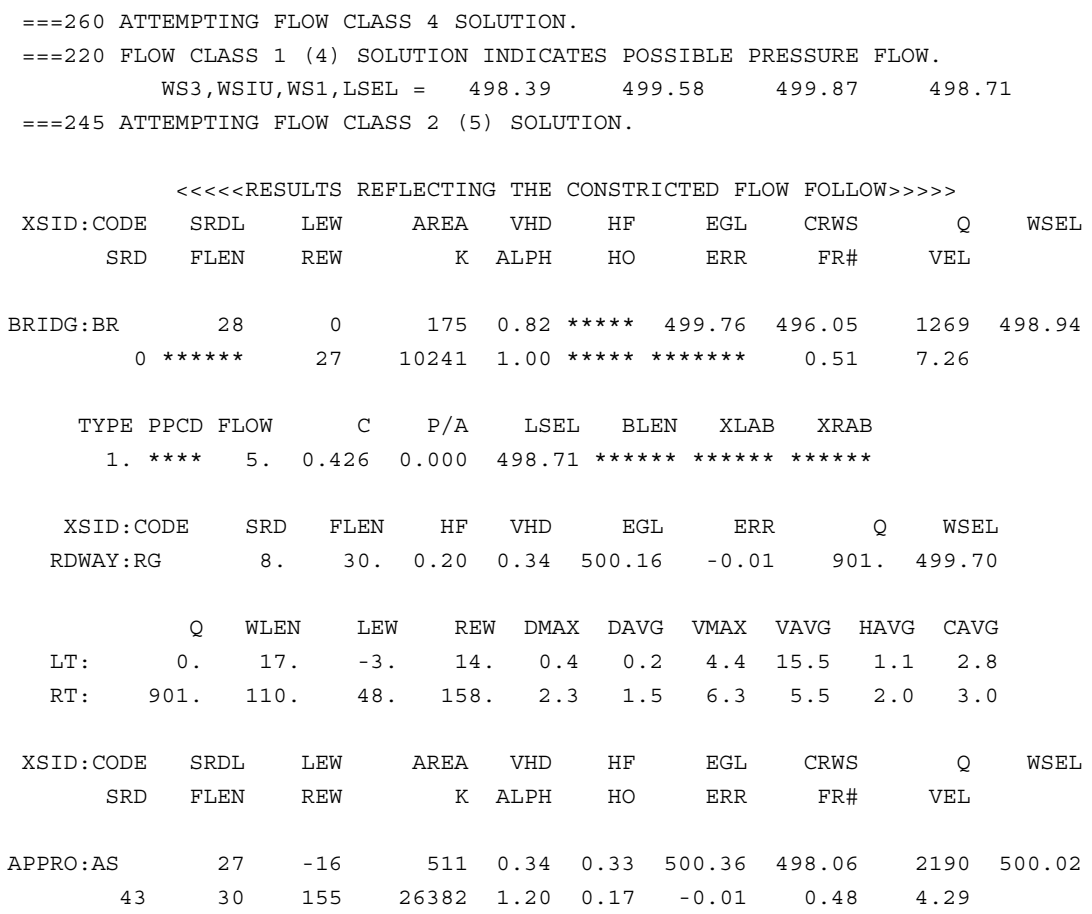

U.S. Geological Survey WSPRO Input File hunt029.wsp

Hydraulic analysis for structure HUNTTH00290029 Date: 02-JUN-97

Bridge \#29 over Cobb Brook in Huntington, Vt. RHF

FIRST USER DEFINED TABLE.

\begin{tabular}{|c|c|c|c|c|c|c|c|c|}
\hline XSID : CODE & SRD & LEW & REW & Q & $\mathrm{K}$ & AREA & VEL & WSEL \\
\hline EXITX:XS & -28 & -15 & 164. & 2190. & 15145. & 320. & 6.85 & 497.73 \\
\hline FULLV : FV & 0 & -17 & 169. & 2190. & 23059 . & 465 . & 4.71 & 498.64 \\
\hline BRIDG : BR & 0. & 0 . & 27. & 1269. & 10241 . & 175 . & 7.26 & 498.94 \\
\hline RDWAY : RG & $8 .{ }^{x}$ & $\star * \star * *$ & 0 . & 901 & $0 . *$ & $\star * * * * *$ & 2.00 & 499.70 \\
\hline APPRO: AS & 43. & -17 & 155. & 2190. & 26382 . & 511. & 4.29 & 500.02 \\
\hline XSID: CODE & XLKQ & $\mathrm{XRKQ}$ & & & & & & \\
\hline
\end{tabular}

SECOND USER DEFINED TABLE.

\begin{tabular}{|c|c|c|c|c|c|c|c|c|}
\hline XSID : CODE & CRWS & FR\# & YMIN & YMAX & $\mathrm{HF}$ & VHD & EGL & WSEL \\
\hline EXITX:XS & 497.73 & 1.04 & 491.07 & $509.21 * *$ & 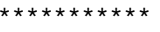 & 0.96 & 498.69 & 497.73 \\
\hline FULLV : FV & 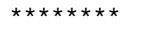 & 0.59 & 491.18 & 509.32 & 0.00 & 0.44 & 499.07 & 498.64 \\
\hline BRIDG : BR & 496.05 & 0.51 & 490.72 & $498.94 * *$ & 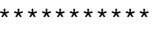 & 0.82 & 499.76 & 498.94 \\
\hline RDWAY : RG & 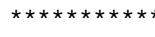 & 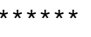 & 497.39 & 514.45 & $0.20 * * * * * *$ & 0.34 & 500.16 & 499.70 \\
\hline APPRO: AS & 498.06 & 0.48 & 491.60 & 506.33 & 0.17 & 0.34 & 500.36 & 500.02 \\
\hline
\end{tabular}

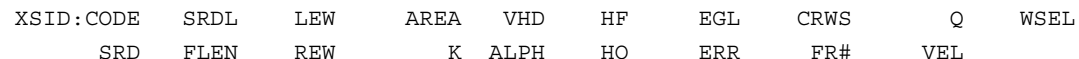

EXITX:XS $\quad * * * * * * \quad-9 \quad 151 \quad 0.79 * * * * * \quad 496.67 \quad 495.05 \quad 1080 \quad 495.88$ $\begin{array}{rllllll}-27 * * * * * & 36 & 6966 & 1.00 * * * * * * * * * * * * & 0.69 & 7.13\end{array}$

$\begin{array}{llllllllll} & 28 & -10 & 181 & 0.55 & 0.52 & 497.18 * * * * * * * & 1080 & 496.63\end{array}$

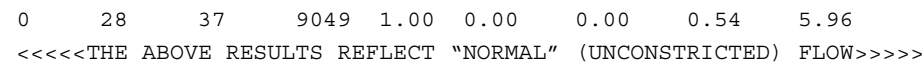

$\begin{array}{llllllllll}\text { APPRO:AS } & 43 & -13 & 176 & 0.62 & 0.71 & 497.93 & * * * * * * * & 1080 & 497.30\end{array}$

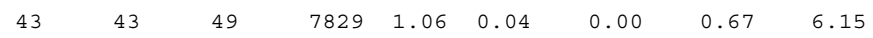
$<<<<$ THE ABOVE RESULTS REFLECT "NORMAL" (UNCONSTRICTED) FLOW >>>>>

$===215$ FLOW CLASS 1 SOLUTION INDICATES POSSIBLE ROAD OVERFLOW.
WS1, WSSD ,WS3, RGMIN $=498.08$
0.00
495.82
497.39

$===260$ ATTEMPTING FLOW CLASS 4 SOLUTION. 


\section{APPENDIX C:}

\section{BED-MATERIAL PARTICLE-SIZE DISTRIBUTION}




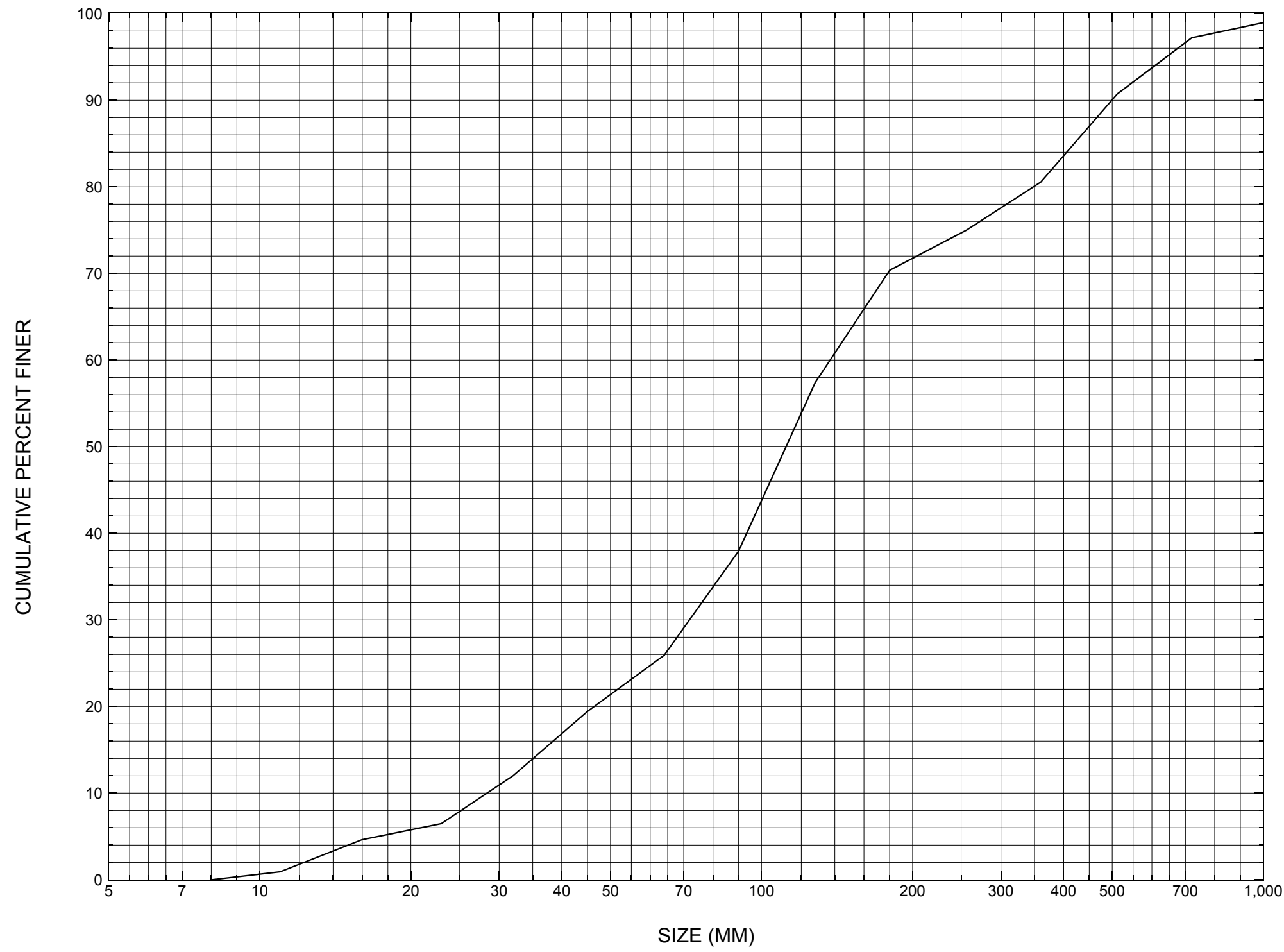

Appendix C. Bed material particle-size distribution for a pebble count in the channel approach of structure HUNTTH00290029, in Huntington, Vermont. 


\section{APPENDIX D: \\ HISTORICAL DATA FORM}




\section{Structure Number HUNTTH00290029}

\section{General Location Descriptive}

Data collected by (First Initial, Full last name) $\underline{\text { L. }}$. Medalie

Date $(M M / D D / Y Y)+12 / 11 / 95$

Highway District Number (I - 2; nn) $\mathbf{0 5}$

Town (FIPS place code; I - 4; nnnnn) $\mathbf{3 4 6 0 0}$

Waterway (I - 6) COBB BROOK

Route Number C3029

Topographic Map Huntington

Latitude (I - 16; nnnn.n) $\mathbf{4 4 1 6 4}$
County (FIPS county code; I - 3; nnn)

Mile marker (I - 11; nnn.nnn) $\mathbf{0 0 0 0 0 0}$

Road Name (I - 7): CHARLES SMITH

Vicinity (I - 9) 0.2 MI TO JCT W CL2 TH1

Hydrologic Unit Code: -

Longitude (i - 17; nnnnn.n) $\mathbf{7 2 5 7 5}$

\section{Select Federal Inventory Codes}

FHWA Structure Number (I - 8) $\mathbf{1 0 0 4 0 8 0 0 2 9 0 4 0 8}$

Maintenance responsibility $(I-21 ; n n) \quad \mathbf{0 3}$

Year built (I - 27; YYYY) 1914

Average daily traffic, ADT (I - 29; nnnnnn) $\underline{000010}$

Year of ADT (I - 30; YY) $\mathbf{9 3}$

Opening skew to Roadway $(I-34 ; n n) \quad \mathbf{0 0}$

Operational status $(I-41 ; X) \quad \mathbf{P}$

Structure type (I - 43; nnn) $\mathbf{3 0 2}$

Approach span structure type $(I-44 ; n n n) \quad \mathbf{0 0 0}$

Number of spans (I - 45; nnn) $\mathbf{0 0 1}$

Number of approach spans (I - 46; nnnn) $\mathbf{0 0 0 0}$

Comments:

According to the structural inspection report dated 7/3/95, the deck consists of 2x6's on edge with wood plank runners. Abutments and wing/retainer walls are concrete, or possibly concrete faced laid up stone. The right abutment has a 1' to 1.5 ' by 2 " to 3" deep undermined area in its bottom DS corner where a large boulder has been encased in the concrete. There are minor cracks and spalls overall. Each abutment has a treated timber plank backwall. Numerous large boulders are present in the US and DS channel, with large areas of erosion showing along the US and DS embankments. Ledge outcrops are showing in both US and DS channel.
Maximum span length (I - 48; nnnn) $\underline{\mathbf{0 0 3 0}}$

Structure length (I - 49; nnnnnn) $\underline{000036}$

Deck Width (I - 52; nn.n) 134

Channel \& Protection $(I-61 ; n) \underline{5}$

Waterway adequacy $(I-71 ; n) \underline{6}$

Underwater Inspection Frequency $(I-92 B ; X Y Y) \_$N

Year Reconstructed (I - 106) 1938

Clear span (nnn.n ft) _

Vertical clearance from streambed (nnn.n ft) $\underline{\mathbf{7 . 5}}$

Waterway of full opening $\left(n n n . n \mathrm{ft}^{2}\right)$ 


\section{Bridge Hydrologic Data}

Is there hydrologic data available? $\underline{\mathbf{N}}$ if No, type ctrl- $n$ VTAOT Drainage area $\left(m i^{2}\right)$ :

Terrain character:

Stream character \& type: -

Streambed material: Sand and gravel with few boulders

Discharge Data (cfs): $\quad \mathrm{Q}_{2.33}$

$$
\mathrm{Q}_{50}-
$$

$\mathrm{Q}_{10}-$

$$
\begin{aligned}
& Q_{25} \ldots \\
& Q_{500}-
\end{aligned}
$$

Record flood date (MM/DD/YY): - $/$ - $/$ Water surface elevation $(f t):-$

Estimated Discharge (cfs): Velocity at $\mathrm{Q}-$ $(\mathrm{ft} / \mathrm{s}):$

Ice conditions (Heavy, Moderate, Light) : -

Debris (Heavy, Moderate, Light):

The stage increases to maximum highwater elevation (Rapidly, Not rapidly):

The stream response is (Flashy, Not flashy):

Describe any significant site conditions upstream or downstream that may influence the stream's stage: -

Watershed storage area (in percent):

The watershed storage area is: - _ (1-mainly at the headwaters; 2- uniformly distributed; 3-immediatly upstream oi the site)

Water Surface Elevation Estimates for Existing Structure:

\begin{tabular}{|l|l|l|l|l|l|}
\hline Peak discharge frequency & $Q_{2.33}$ & $Q_{10}$ & $Q_{25}$ & $Q_{50}$ & $Q_{100}$ \\
Water surface elevation (ft)) & - & - & - & - & - \\
Velocity (ft/sec) & - & - & - & - & - \\
\hline
\end{tabular}

Long term stream bed changes: -

Is the roadway overtopped below the $Q_{100}$ ? (Yes, No, Unknown): Frequency: -

Relief Elevation (ft):

Discharge over roadway at $Q_{100}\left(f^{3} / \mathrm{sec}\right)$ :

Are there other structures nearby? (Yes, No, Unknown): Upstream distance (miles): Town: If No or Unknown, type ctrl-n os Highway No. : Structure No. : Year Built:

Clear span (ft): Clear Height $(f t)$ : Full Waterway $\left(f t^{2}\right)$ : 
Downstream distance (miles): Town: Year Built:

Highway No. : Structure No. : Structure Type:

Clear span $(f t):$ Clear Height $(f t)$ : Full Waterway $\left(f^{2}\right):$

Comments:

\section{USGS Watershed Data}

Watershed Hydrographic Data

Drainage area $(D A)$

4.16 $\mathrm{mi}^{2}$

Watershed storage (ST) 0.24

Bridge site elevation 790

Main channel length 3.94 $10 \%$ channel length elevation $\mathbf{9 5 0}$ $\mathrm{ft} \quad 85 \%$ channel length elevation $\mathrm{ft}$

Main channel slope $(S)$

(S) 588.83 $\mathrm{ft} / \mathrm{mi}$

Watershed Precipitation Data

Average site precipitation in Average headwater precipitation in

Maximum 2yr-24hr precipitation event $(124,2)$ in

Average seasonal snowfall (Sn) $\mathrm{ft}$ 


\section{Bridge Plan Data}

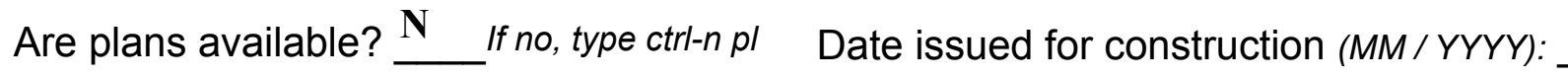

Project Number -

Minimum channel bed elevation:

Low superstructure elevation: USLAB DSLAB USRAB DSRAB Benchmark location description:

-

Reference Point (MSL, Arbitrary, Other):

Datum (NAD27, NAD83, Other):

Foundation Type:

(1-Spreadfooting; 2-Pile; 3- Gravity; 4-Unknown)

If 1: Footing Thickness _ _ _ Footing bottom elevation: -

If 2: Pile Type: (1-Wood; 2-Steel or metal; 3-Concrete)

Approximate pile driven length: -

If 3 : Footing bottom elevation:

Is boring information available? If no, type ctrl-n bi Number of borings taken:

Foundation Material Type: (1-regolith, 2-bedrock, 3-unknown)

Briefly describe material at foundation bottom elevation or around piles:

Comments:

- 


\section{Cross-sectional Data}

Is cross-sectional data available? $\mathbf{Y}$

If no, type ctrl-n xs

Source (FEMA, VTAOT, Other)? VTAOT

This cross-section is at the upstream face. The low chord to bed length data is from the sketch Comments: attached to a bridge inspection report dated 7/03/95. The sketch was done on 10/27/93. There is no accurate low chord elevation data available.

\begin{tabular}{|l|l|l|l|l|l|l|l|l|l|l|l|}
\hline Station & $\mathbf{0}$ & $\mathbf{8}$ & $\mathbf{1 3}$ & $\mathbf{2 1}$ & $\mathbf{2 7 . 4}$ & - & - & - & - & - & - \\
\hline Feature & LAB & - & - & - & $\mathbf{R A B}$ & - & - & - & - & - & - \\
\hline $\begin{array}{l}\text { Low cord } \\
\text { elevation }\end{array}$ & - & - & - & - & - & - & - & - & - & - & - \\
\hline $\begin{array}{l}\text { Bed } \\
\text { elevation }\end{array}$ & - & - & - & - & - & - & - & - & - & - & - \\
\hline $\begin{array}{l}\text { Low cord to } \\
\text { bed length }\end{array}$ & $\mathbf{7 . 0}$ & $\mathbf{8 . 1}$ & $\mathbf{7 . 7}$ & $\mathbf{6 . 8}$ & $\mathbf{5 . 0}$ & - & - & - & - & - & - \\
\hline Station & - & - & - & - & - & - & - & - & - & - & - \\
\hline Feature & - & - & - & - & - & - & - & - & - & - & - \\
\hline $\begin{array}{l}\text { Low cord } \\
\text { elevation }\end{array}$ & - & - & - & - & - & - & - & - & - & - & - \\
\hline $\begin{array}{l}\text { Bed } \\
\text { elevation }\end{array}$ & - & - & - & - & - & - & - & - & - & - & - \\
\hline $\begin{array}{l}\text { Low cord to } \\
\text { bed length }\end{array}$ & - & - & - & - & - & - & - & - & - & - & - \\
\hline
\end{tabular}

Source (FEMA, VTAOT, Other)?

Comments: -

\begin{tabular}{|l|l|l|l|l|l|l|l|l|l|l|l|}
\hline Station & - & - & - & - & - & - & - & - & - & - & - \\
\hline Feature & - & - & - & - & - & - & - & - & - & - & - \\
\hline $\begin{array}{l}\text { Low cord } \\
\text { elevation }\end{array}$ & - & - & - & - & - & - & - & - & - & - & - \\
\hline $\begin{array}{l}\text { Bed } \\
\text { elevation }\end{array}$ & - & - & - & - & - & - & - & - & - & - & - \\
\hline $\begin{array}{l}\text { Low cord to } \\
\text { bed length }\end{array}$ & - & - & - & - & - & - & - & - & - & - & - \\
\hline Station & - & - & - & - & - & - & - & - & - & - & - \\
\hline Feature & - & - & - & - & - & - & - & - & - & - & - \\
\hline $\begin{array}{l}\text { Low cord } \\
\text { elevation }\end{array}$ & - & - & - & - & - & - & - & - & - & - & - \\
\hline $\begin{array}{l}\text { Bed } \\
\text { elevation }\end{array}$ & - & - & - & - & - & - & - & - & - & - & - \\
\hline $\begin{array}{l}\text { Low cord to } \\
\text { bed length }\end{array}$ & - & - & - & - & - & - & - & - & - & - & - \\
\hline
\end{tabular}




\section{APPENDIX E: \\ LEVEL I DATA FORM}


U. S. Geological Survey

Bridge Field Data Collection and Processing Form

Qa/Qc Check by: EW Date: $10 / \mathbf{1 0 / 9 6}$

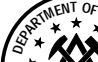

\section{Structure Number}

HUNTTH00290029

\section{A. General Location Descriptive}

1. Data collected by (First Initial, Full last name) M. IVANOFF

2. Highway District Number $\mathbf{0 5}$

County WASHINGTON 007

Mile marker $\mathbf{0 0 0 0 0 0}$

Waterway (I - 6) COBB BROOK

Route Number TH029

Town HUNTINGTON 34600

Road Name CHARLES SMITH

Hydrologic Unit Code:

3. Descriptive comments:

The structure is located 0.2 miles from the junction with Town Highway 1.

\section{B. Bridge Deck Observations}
4. Surface cover... LBUS 6
RBUS 6
LBDS 6
RBDS 6
Overall 6

(2b us,ds,lb,rb: 1- Urban; 2- Suburban; 3- Row crops; 4- Pasture; 5- Shrub- and brushland; 6- Forest; 7- Wetland)
5. Ambient water surface... US 2
UB 1
DS 2
(1- pool; 2- riffle)

6. Bridge structure type 1 (1- single span; 2- multiple span; 3- single arch; 4- multiple arch; 5-cylindrical culvert; 6- box culvert; or 7- other)
7. Bridge length $\underline{36}$
(feet)
Span length $\underline{\mathbf{3 0}}$
(feet)
Bridge width 13.4 (feet)

\section{Road approach to bridge:}

\section{LB 2 RB 1 ( 0 even, 1- lower, 2- higher) \\ 9. LB 2 RB $\underline{2}$ (1-Paved, 2- Not paved)}

10. Embankment slope (run / rise in feet / foot)

US left

US right

\begin{tabular}{|c|c|c|c|}
\hline \multicolumn{2}{|c|}{ Protection } & \multirow{2}{*}{ 13.Erosion } & 14.Severity \\
\hline 11.Type & 12.Cond. & $\mathbf{0}$ & - \\
\hline $\mathbf{2}$ & $\mathbf{1}$ & $\mathbf{0}$ & - \\
$\mathbf{0}$ & - & $\mathbf{0}$ & - \\
\hline $\mathbf{5}$ & $\mathbf{1}$ & $\mathbf{0}$ & - \\
\hline $\mathbf{0}$ & $\mathbf{-}$ & $\mathbf{2}$ & $\mathbf{1}$ \\
\hline
\end{tabular}

Bank protection types: 0- none; 1- < 12 inches,

2- $<36$ inches; $3-<48$ inches

4- < 60 inches; 5- wall / artificial levee

Bank protection conditions: 1- good; 2- slumped;

3- eroded; 4- failed

Erosion: 0 - none; 1- channel erosion; 2 -

road wash; 3- both; 4- other

Erosion Severity: 0 - none; 1- slight; 2- moderate; 3- severe

\section{Channel approach to bridge (BF):}

15. Angle of approach: 10

16. Bridge skew: 25

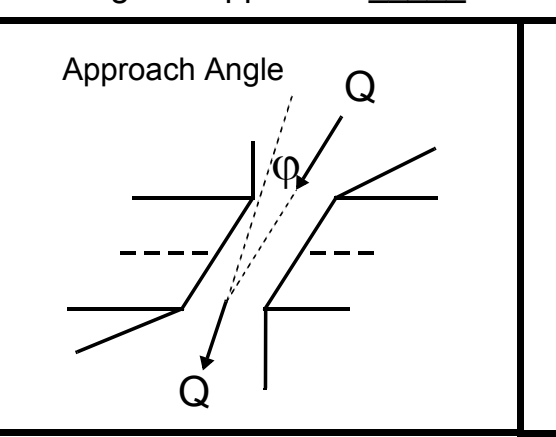

17. Channel impact zone 1:

Where? LB $(L B, R B)$

Exist? $\mathbf{Y}$ (Y or $N)$ Bridge Skew Angle

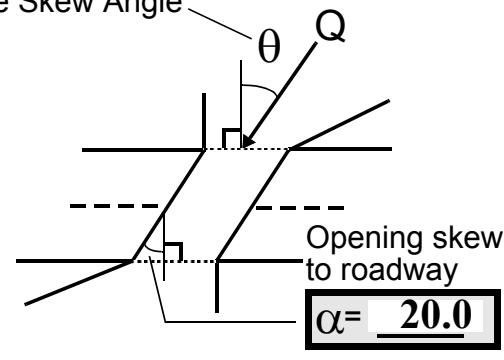

Range? 90 feet $\underline{\text { US }}$

Severity 2

Channel impact zone 2:

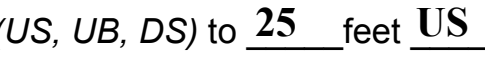

Where? RB (LB, RB)

Exist? $\mathbf{Y}(Y$ or $N)$

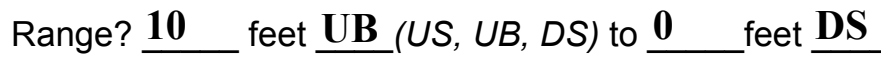

Impact Severity: 0- none to very slight; 1-Slight; 2- Moderate; 3- Severe 
18. Bridge Type: $\mathbf{1 b}$

1a- Vertical abutments with wingwalls

$1 \mathrm{~b}$ - Vertical abutments without wingwalls

2- Vertical abutments and wingwalls, sloping embankment Wingwalls perpendicular to abut. face

3- Spill through abutments

4- Sloping embankment, vertical wingwalls and abutments

Wingwall angle less than $90^{\circ}$.

19. Bridge Deck Comments (surface cover variations, measured bridge and span lengths, bridge type variations, approach overflow width, etc.)

\#4: The downstream right bank surface cover is forest with TH29 along the downstream right bank.

\#7: All measured values correspond with VTAOT values on the historical form.

\#11: The downstream right bank road approach protection is a wood plank retaining wall for road gravel extending eight feet.

\section{Upstream Channel Assessment}

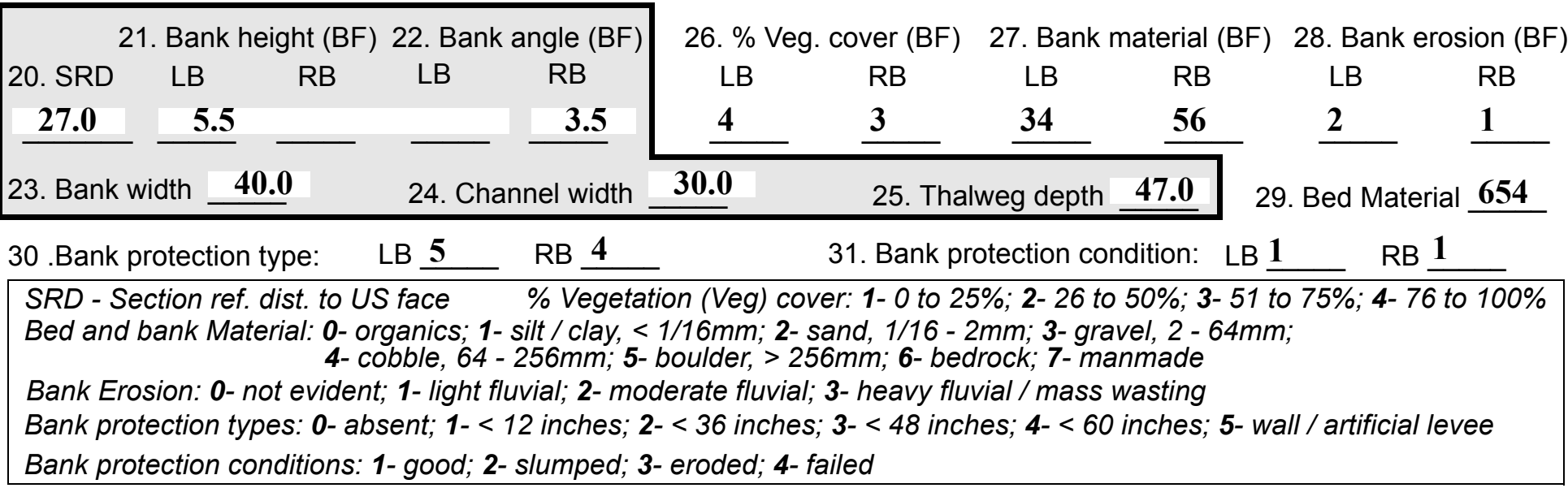

32. Comments (bank material variation, minor inflows, protection extent, etc.):

\#27: The right bank consists of large boulders and some bedrock.

\#29: The bed material consists of boulders, bedrock and cobble.

\#30: The left bank protection extends from the end of the wingwall to 20 feet upstream.

At 60 feet upstream, a large group of boulders exists in the channel bed.

At 85 feet upstream, bedrock is exposed and extends further upstream.

Channel widens from the upstream bridge face to 94 feet upstream. 
33.Point/Side bar present? Y

$(Y$ or $N$. if $N$ type ctrl-n pb) 34 . Mid-bar distance: $\mathbf{4 0}$

35. Mid-bar width: $\mathbf{3 0}$

36. Point bar extent: 94 feet US

(US, UB) to 10 feet $\underline{\mathbf{U S}}$

(US, UB, DS) positioned $\underline{\mathbf{0}}$

$\%$ LB to $\mathbf{7 0}$ $\%$ RB

37. Material: 43

38. Point or side bar comments (Circle Point or Side; Note additional bars, material variation, status, etc.):

Side bar is located in a widened channel zone with a cut-bank consisting of cobble and gravel.

39. Is a cut-bank present? $\mathbf{Y}$ ( $Y$ or if $N$ type ctrl-n $c b)$

40. Where? $\mathbf{L B} \quad(L B$ or $R B)$

41. Mid-bank distance: $\mathbf{5 5}$

42. Cut bank extent: 94

US, UB) to 15 feet $\underline{\mathbf{U S}}$ (US, UB, DS)

43. Bank damage: 1

(1- eroded and/or creep; 2- slip failure; 3- block failure)

44. Cut bank comments (eg. additional cut banks, protection condition, etc.):

Cut-bank begins at bedrock outcrop where channel widens and a side bar forms.

45. Is channel scour present? $\mathbf{Y}$ ( $Y$ or if $N$ type ctrl-n cs)

47. Scour dimensions: Length $\mathbf{2 2}$

Width 10

Depth : 1.5

46. Mid-scour distance: $\underline{2 \text { US }}$

48. Scour comments (eg. additional scour areas, local scouring process, etc.):

Bridge scour extends from 12 feet upstream to 10 feet under bridge.

49. Are there major confluences? $\mathbf{N}$

51. Confluence 1: Distance -

Confluence 2: Distance -

54. Confluence comments (eg. confluet

NO MAJOR CONFLUENCES
( $Y$ or if $N$ type ctrl-n mc)

52. Enters on -

Enters on (LB or $R B)$ (LB or $R B)$
50. How many? -

53. Type(1- perennial; 2- ephemeral)

Type (1- perennial; 2- ephemeral)

\section{Under Bridge Channel Assessment}

55. Channel restraint (BF)? LB 2

56. Height (BF)
LB RB
$\mathbf{3 5 . 5}-$
58. Bank width (BF) -
59. Channel width $(\mathrm{Amb})$ (1- natural bank; 2- abutment; 3- artificial levee)

Bed and bank Material: 0- organics; 1- silt / clay, < 1/16mm; 2- sand, 1/16 - 2mm; 3- gravel, 2 - 64mm; 4- cobble, 64 - 256mm; 5- boulder, > 256mm; 6- bedrock; 7- manmade

Bank Erosion: 0- not evident; 1- light fluvial; 2- moderate fluvial; 3- heavy fluvial / mass wasting

64. Comments (bank material variation, minor inflows, protection extent, etc.):

543 
65. Debris and Ice Is there debris accumulation?

(Yor $N)$ 66. Where? $\underline{Y}$

(1- Upstream; 2- At bridge; 3- Both)

67. Debris Potential 1 ( 1- Low; 2- Moderate; 3- High)

68. Capture Efficiency 2

(1- Low; 2- Moderate; 3- High)

69. Is there evidence of ice build-up? 2 (Y or $N)$

Ice Blockage Potential $\mathbf{N}$

(1-Low; 2- Moderate; 3- High)

70. Debris and Ice Comments:

2

At 50 feet upstream, logs are across the channel and trees are leaning into the stream. There are also dead trees along both upstream banks.

\begin{tabular}{|l|c|c|c|c|c|c|c|c|}
\hline Abutments & $\begin{array}{c}\text { 71. Attack } \\
\angle \text { (BF) }\end{array}$ & $\begin{array}{c}\text { 72. Slope } \angle \\
\text { (Qmax) }\end{array}$ & $\begin{array}{c}\text { 73. Toe } \\
\text { loc. (BF) }\end{array}$ & $\begin{array}{c}\text { 74. Scour } \\
\text { Condition }\end{array}$ & $\begin{array}{c}75 . \text { Scour } \\
\text { depth }\end{array}$ & $\begin{array}{c}\text { 76. Exposure } \\
\text { depth }\end{array}$ & 77. Material & 78. Length \\
\hline LABUT & & $\mathbf{0}$ & $\mathbf{8 3}$ & $\mathbf{2}$ & $\mathbf{1}$ & $\mathbf{1 . 5}$ & $\mathbf{0}$ & $\mathbf{9 0 . 0}$ \\
\hline RABUT & $\mathbf{1}$ & $\mathbf{1 5}$ & $\mathbf{9 0}$ & & & $\mathbf{2}$ & $\mathbf{3}$ & $\mathbf{2 5 . 5}$ \\
\hline
\end{tabular}

Pushed: $L B$ or RB

Toe Location (Loc.): 0- even, 1- set back, 2- protrudes

Scour cond.: 0- not evident; 1- evident (comment); 2- footing exposed; 3-undermined footing; 4- piling exposed; 5- settled; 6- failed

Materials: 1- Concrete; 2- Stone masonry or drywall; 3- steel or metal; 4- wood

79. Abutment comments (eg. undermined penetration, unusual scour processes, debris, etc.):

1.2

0.4

1

The right abutment is undermined along three feet of the downstream end, below the boulder and concrete of the abutment. Penetration depth is a maximum of 1 foot. Scour depth is 1.2 feet at the downstream corner of the right abutment. Undermining depth is 0.4 feet below the concrete base of the abutment at the upstream end of the boulder in the wall. This is also described in historical form.

80. Wingwalls:

$\begin{array}{lllll} & & & \\ \text { Exist? Material? } & \text { Scour } & \text { Scour } & \text { Exposure } & \text { Angle? Length? } \\ & \text { Condition? depth? } & \text { depth? }\end{array}$

USLWW:

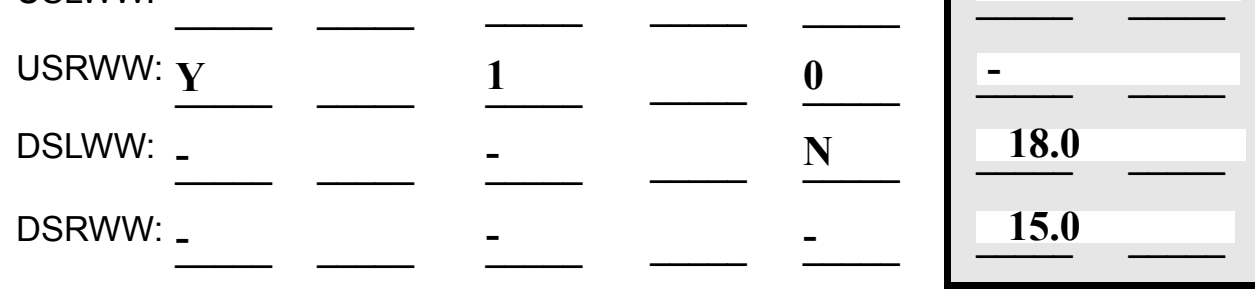

Wingwall materials: 1- Concrete; 2- Stone masonry or drywall; 3- steel or metal; 4- wood

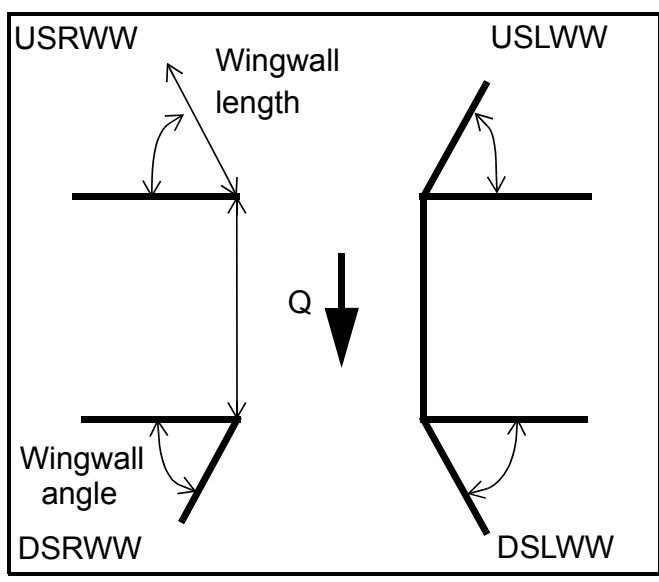

82. Bank / Bridge Protection:

\begin{tabular}{|l|l|l|l|l|l|l|c|c|}
\hline Location & USLWW & USRWW & LABUT & RABUT & LB & RB & DSLWW & DSRWW \\
\hline Type & - & $\mathbf{0}$ & $\mathbf{N}$ & - & $\mathbf{1}$ & - & - & $\mathbf{3}$ \\
\hline Condition & $\mathbf{Y}$ & - & - & - & $\mathbf{2}$ & - & - & $\mathbf{2}$ \\
\hline Extent & $\mathbf{1}$ & - & - & $\mathbf{3}$ & - & $\mathbf{0}$ & $\mathbf{2}$ & - \\
\hline
\end{tabular}

Bank / Bridge protection types: 0- absent; 1- < 12 inches; 2- < 36 inches; 3- < 48 inches; 4- < 60 inches; 
83. Wingwall and protection comments (eg. undermined penetration, unusual scour processes, etc.):

-
-
-
-
0
-
-
-
-
-

\section{Piers:}

84. Are there piers? \#82 (Y or if $N$ type ctrl-n pr)

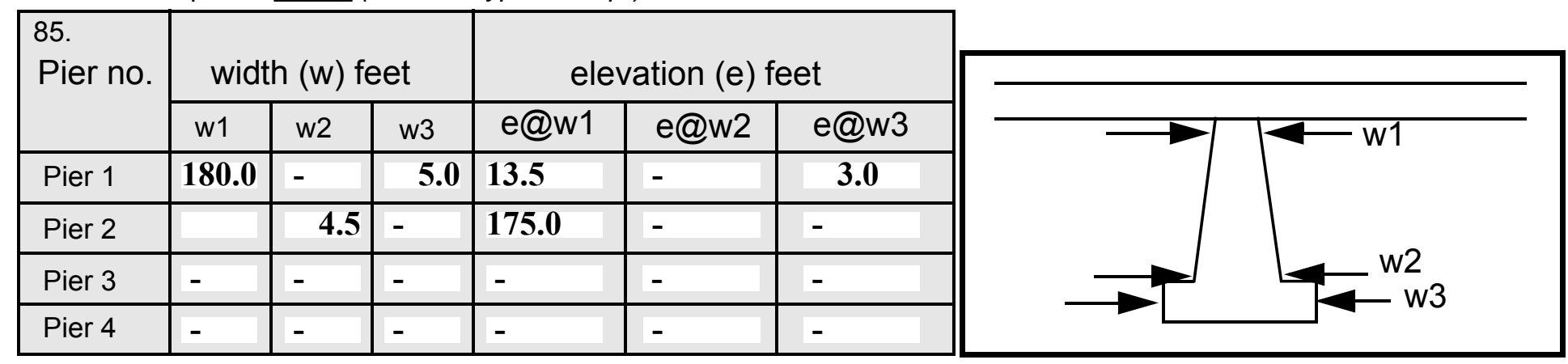

\begin{tabular}{|l|l|l|l|l|}
\hline Level 1 Pier Descr. & \multicolumn{1}{|c|}{1} & \multicolumn{1}{|c|}{2} & \multicolumn{1}{|c|}{3} & \multicolumn{1}{|c|}{4} \\
\hline 86. Location (BF) & At & ders & a few & areas \\
\hline 87. Type & the & are & have & wher \\
\hline 88. Material & upst & emb & been & e \\
\hline 89. Shape & ream & edde & place & these \\
\hline 90. Inclined? & end & d & d in & boul- \\
\hline 91. Attack $\angle$ (BF) & of & into & front & ders \\
\hline 92. Pushed & the & the & of & do \\
\hline 93. Length (feet) & - & - & - & - \\
\hline 94. \# of piles & right & con- & the & not \\
\hline 95. Cross-members & abut & crete & abut & exist, \\
\hline 96. Scour Condition & ment & abut & ment & scou \\
\hline 97. Scour depth & , & ment & . In & r, \\
\hline 98. Exposure depth & boul- & and & those & foot- \\
\hline
\end{tabular}

LFP, LTB, LB, MCL, MCM, MCR, RB, RTB, RFP

1- Solid pier, 2-column, 3- bent

1-Wood; 2-concrete; 3- metal; 4- stone

1- Round; 2- Square; 3- Pointed

Y-yes; $N$ - no

$L B$ or $R B$

0- none; 1- laterals; 2- diagonals; 3- both

0- not evident; 1- evident (comment);

2- footing exposed; 3- piling exposed;

4- undermined footing; 5- settled; 6- failed 
99. Pier comments (eg. undermined penetration, protection and protection extent, unusual scour processes, etc.): ing exposure and penetration are evident.

$\mathbf{N}$

100.

\section{E. Downstream Channel Assessment}

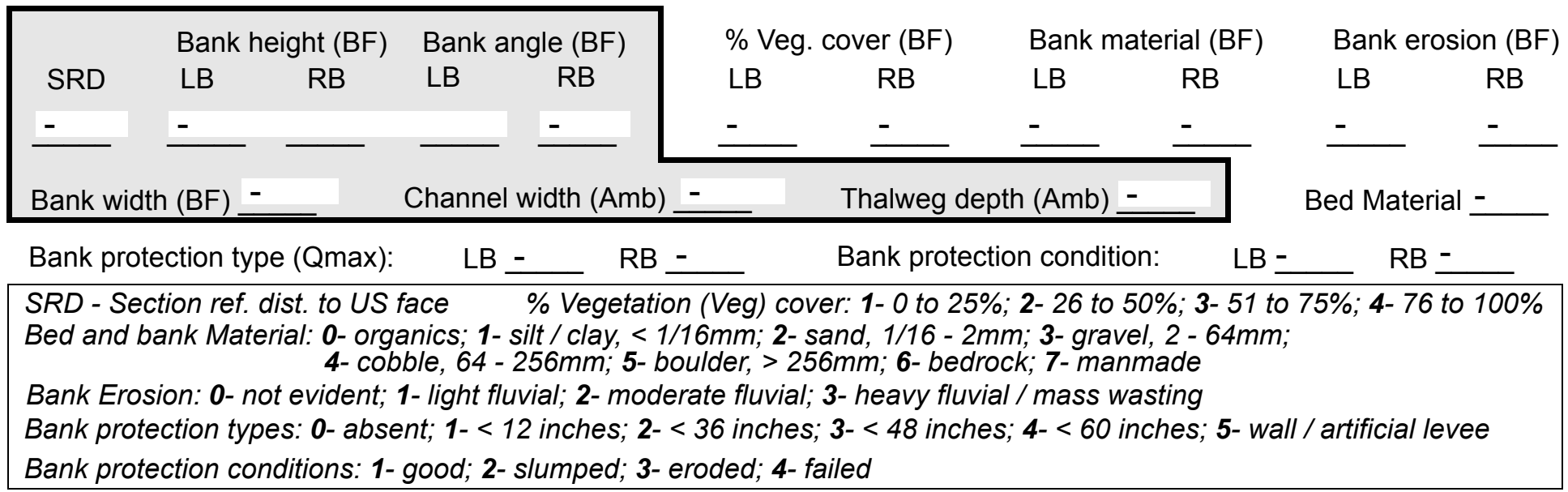

Comments (eg. bank material variation, minor inflows, protection extent, etc.):

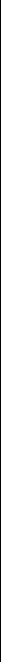

\section{Is a drop structure present? __ ( $Y$ or $N$, if $N$ type ctrl-n $d s) \quad$ 102. Distance: ___ feet}

103. Drop: -_ feet 104. Structure material: ___ (1- steel sheet pile; 2- wood pile; 3- concrete; 4- other)

105. Drop structure comments (eg. downstream scour depth): 
106. Point/Side bar present? (Y or $N$. if $N$ type ctrl-n pb)Mid-bar distance:

Mid-bar width: -

Point bar extent: feet -

(US, UB, DS) to feet (US, UB, DS) positioned $\%$ LB to $\% \mathrm{RB}$ Material:

Point or side bar comments (Circle Point or Side; note additional bars, material variation, status, etc.):

S a cut-bank present? $\mathbf{N}$ (Y or if $N$ type ctrl-n cb) Where? $\underline{\mathbf{O}}$ (LB or RB) Mid-bank distance: PIE Cut bank extent: $\underline{\mathbf{R S}}$ feet __ (US, UB, DS) to feet ___ (US, UB, DS)

Bank damage: (1- eroded and/or creep; 2- slip failure; 3- block failure)

Cut bank comments (eg. additional cut banks, protection condition, etc.):

Is channel scour present? ( $Y$ or if $N$ type ctrl-n cs) Width 346 Depth: 45

Mid-scour distance: $\underline{4}$ Scour dimensions: Length 4 Scour comments (eg. additional scour areas, local scouring process, etc.): 635

$\mathbf{0}$

0

Are there major confluences? - (Yor if $N$ type ctrl-n mc)

Confluence 1: Distance left Enters on ban ( $L B$ or RB)

Enters on rial (LB or $R B)$

Positioned 2 $\%$ LB to 1 $\% \mathrm{RB}$

Confluence comments (eg. confluence name):

sists of gravel and cobble with bedrock beginning at $\mathbf{7 0}$ feet downstream and extending farther downstream.

\section{F. Geomorphic Channel Assessment}

107. Stage of reach evolution

1- Constructed

2- Stable

3- Aggraded

4- Degraded

5- Laterally unstable

6- Vertically and laterally unstable 
108. Evolution comments (Channel evolution not considering bridge effects; See HEC-20, Figure 1 for geomorphic descriptors):

e right bank material consists of cobbles and boulders.

A bedrock outcrop extends across channel creating a drop of 4 feet at 86 feet downstream from bridge. 


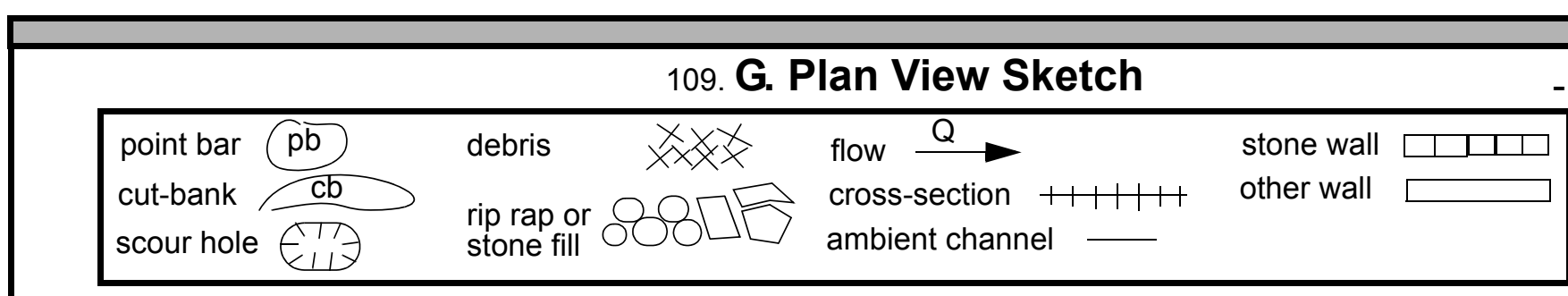


APPENDIX F:

SCOUR COMPUTATIONS 


\begin{tabular}{|c|c|c|c|c|}
\hline Structure Number: HUNTTH00290029 & & Town: & HUNTINGT & \\
\hline $\begin{array}{l}\text { Road Number: } \quad \text { TH29 } \\
\text { Stream: Cobb Brook }\end{array}$ & & County: & CHITTEND & \\
\hline Initials RHF & Checked: & MAI & & \\
\hline $\begin{array}{l}\text { Analysis of contraction scour, liv } \\
\text { Critical Velocity of Bed Material } \\
\text { VC=11.21*Y1^0.1667*D50^0.33 with S } \\
\text { (Richardson and others, 1995, p. } 2\end{array}$ & $\begin{array}{l}\text {-bed or cl } \\
\text { converted } \\
=2.65 \\
\text {, eq. 16) }\end{array}$ & $\begin{array}{l}\text { ear wat } \\
\text { to Eng }\end{array}$ & ?h units) & \\
\hline Approach Section & & & & \\
\hline Characteristic & $100 \mathrm{yr}$ & $500 \mathrm{yr}$ & other $Q$ & other $Q$ \\
\hline Total discharge, cfs & 1190 & 2190 & 1080 & 1740 \\
\hline Main Channel Area, ft2 & 207 & 289 & 200 & 245 \\
\hline Left overbank area, ft2 & 0 & 0 & 0 & 0 \\
\hline Right overbank area, ft2 & 35 & 222 & 30 & 72 \\
\hline Top width main channel, ft & 45 & 47 & 45 & 46 \\
\hline Top width L overbank, ft & 0 & 0 & 0 & 0 \\
\hline Top width $\mathrm{R}$ overbank, ft & 36 & 125 & 33 & 51 \\
\hline D50 of channel, ft & 0.3672 & 0.3672 & 0.3672 & 0.3672 \\
\hline D50 left overbank, ft & -- & -- & -- & -- \\
\hline D50 right overbank, ft & -- & -- & -- & -- \\
\hline y1, average depth, $M C$, ft & 4.6 & 6.1 & 4.4 & 5.3 \\
\hline y1, average depth, LOB, ft & ERR & ERR & ERR & ERR \\
\hline y1, average depth, ROB, ft & 1.0 & 1.8 & 0.9 & 1.4 \\
\hline Total conveyance, approach & 11758 & 26386 & 11041 & 16424 \\
\hline Conveyance, main channel & 10883 & 18344 & 10331 & 14186 \\
\hline Conveyance, LOB & 0 & 0 & 0 & 0 \\
\hline Conveyance, ROB & 875 & 8042 & 710 & 2238 \\
\hline Percent discrepancy, conveyance & 0.0000 & 0.0000 & 0.0000 & 0.0000 \\
\hline Qm, discharge, MC, Cfs & 1101.4 & 1522.5 & 1010.5 & 1502.9 \\
\hline Q1, discharge, LOB, cfs & 0.0 & 0.0 & 0.0 & 0.0 \\
\hline Qr, discharge, ROB, cfs & 88.6 & 667.5 & 69.5 & 237.1 \\
\hline Vm, mean velocity $\mathrm{MC}$, ft/s & 5.3 & 5.3 & 5.1 & 6.1 \\
\hline V1, mean velocity, LOB, ft/s & ERR & ERR & ERR & ERR \\
\hline Vr, mean velocity, ROB, ft/s & 2.5 & 3.0 & 2.3 & 3.3 \\
\hline Vc-m, crit. velocity, $M C$, ft/s & 10.4 & 10.9 & 10.3 & 10.6 \\
\hline Vc-l, crit. velocity, LOB, ft/s & ERR & ERR & $\mathrm{ERR}$ & ERR \\
\hline Vc-r, crit. velocity, ROB, ft/s & ERR & $\mathrm{ERR}$ & $\mathrm{ERR}$ & $\mathrm{ERR}$ \\
\hline Results & & & & \\
\hline Live-bed(1) or Clear-Water(0) Cont & action $\mathrm{Scc}$ & ur? & & \\
\hline Main Channel & 0 & 0 & 0 & 0 \\
\hline Left Overbank & $\mathrm{N} / \mathrm{A}$ & $\mathrm{N} / \mathrm{A}$ & $\mathrm{N} / \mathrm{A}$ & $\mathrm{N} / \mathrm{A}$ \\
\hline Right Overbank & $\mathrm{N} / \mathrm{A}$ & $\mathrm{N} / \mathrm{A}$ & $\mathrm{N} / \mathrm{A}$ & $\mathrm{N} / \mathrm{A}$ \\
\hline Armoring & & & & \\
\hline $\mathrm{DC}=\left[\left(1.94 * \mathrm{~V}^{\wedge} 2\right) /(5.75 * \log (12.27 * \mathrm{y} / \mathrm{D}\right.$ & $\left.0))^{\wedge} 2\right] /[0$. & $03 *(165$ & $52.4)]$ & \\
\hline $\begin{array}{l}\text { Depth to Armoring }=3 *(1 / \mathrm{PC}-1) \\
\text { (Federal Highway Administration, } 1\end{array}$ & 93 ) & & & \\
\hline Downstream bridge face property & $100-y r$ & $500-y r$ & Other Q & \\
\hline Q, discharge thru bridge $\mathrm{MC}$, cfs & 1140 & 1269 & & \\
\hline
\end{tabular}




\begin{tabular}{|c|c|c|c|c|c|}
\hline Main channel area (DS), ft2 & 109.3 & 172 & \multicolumn{3}{|l|}{101.9} \\
\hline Main channel width (normal), ft & 24.9 & 25.7 & \multicolumn{3}{|l|}{24.8} \\
\hline Cum. width of piers, ft & 0.0 & 0.0 & \multicolumn{3}{|l|}{0.0} \\
\hline Adj. main channel width, ft & 24.9 & 25.7 & \multicolumn{3}{|l|}{24.8} \\
\hline D90, ft & 1.6373 & 1.6373 & \multicolumn{3}{|l|}{1.6373} \\
\hline D95, ft & 2.1016 & 2.1016 & \multicolumn{3}{|l|}{2.1016} \\
\hline Dc, critical grain size, ft & 0.9010 & 0.3589 & \multicolumn{3}{|l|}{0.9666} \\
\hline PC, Decimal percent coarser than Dc & 0.239 & 0.513 & \multicolumn{3}{|l|}{0.227} \\
\hline Depth to armoring, ft & 8.63 & 1.02 & \multicolumn{3}{|l|}{9.87} \\
\hline \multicolumn{6}{|c|}{ Clear Water Contraction Scour in MAIN CHANNEL } \\
\hline \multicolumn{6}{|c|}{$\begin{array}{l}\mathrm{y}^{2}=\left(\mathrm{Q} 2^{\wedge} 2 /\left(131 * \mathrm{Dm}^{\wedge}(2 / 3) * \mathrm{~W} 2^{\wedge} 2\right)\right)^{\wedge}(3 / 7) \quad \text { Converte } \\
\mathrm{ys}=\mathrm{y} 2-\mathrm{y} \_ \text {bridge }\end{array}$} \\
\hline \multicolumn{6}{|c|}{ (Richardson and others, 1995, p. 32, eq. 20, 20a) } \\
\hline Bridge Section & Q100 & Q500 & \multicolumn{3}{|c|}{ Other $\mathrm{Q}$ Other $\mathrm{Q}$} \\
\hline (Q) total discharge, cfs & 1190 & 2190 & \multicolumn{3}{|c|}{$1080 \quad 1740$} \\
\hline (Q) discharge thru bridge, cfs & 1140 & 1269 & \multicolumn{3}{|c|}{$1080 \quad 1347$} \\
\hline Main channel conveyance & 7324 & 10241 & 6594 & \multicolumn{2}{|l|}{10882} \\
\hline Total conveyance & 7324 & 10241 & 6594 & \multicolumn{2}{|l|}{10882} \\
\hline Q2, bridge MC discharge, cfs & 1140 & 1269 & 1080 & \multicolumn{2}{|l|}{1347} \\
\hline Main channel area, ft2 & 109 & 175 & 102 & \multicolumn{2}{|l|}{143} \\
\hline Main channel width (normal), ft & 24.9 & 25.7 & 24.8 & 25.3 & \\
\hline Cum. width of piers in $\mathrm{MC}$, ft & 0.0 & 0.0 & 0.0 & 0.0 & \\
\hline w, adjusted width, ft & 24.9 & 25.7 & 24.8 & 25.3 & \\
\hline y_bridge (avg. depth at br.), ft & 4.39 & 6.80 & 4.11 & 5.66 & \\
\hline Dm, median $(1.25 * \mathrm{D} 50)$, ft & 0.459 & 0.459 & 0.459 & 0.459 & \\
\hline $\mathrm{y}^{2}$, depth in contraction, ft & 4.10 & 4.37 & 3.93 & 4.67 & \\
\hline ys, scour depth (y2-ybridge), ft & -0.29 & -2.43 & -0.18 & -0.99 & \\
\hline $\begin{array}{l}\text { Pressure Flow Scour (contraction sc } \\
\text { Chang pressure flow equation }\end{array}$ & $\begin{array}{l}\text { Dur for } \\
\mathrm{Hb}+\mathrm{Ys}=\mathrm{C}\end{array}$ & rifice $f$ & ow condi & ons ) & \\
\hline $\mathrm{Cq}=1 / \mathrm{Cf} * \mathrm{CC} \quad \mathrm{Cf}=1.5 * \mathrm{Fr}^{\wedge} 0.43 \quad(<=1)$ & $\mathrm{CC}=\mathrm{SQRT}$ & $0.10(\mathrm{Hb} /($ & $(y a-w)-0.5$ & 6) $]+0.79$ & $(<=1)$ \\
\hline $\begin{array}{l}\text { Umbrell pressure flow equation } \\
(\mathrm{Hb}+\mathrm{Ys}) / \mathrm{ya}=1.1021 *[(1-\mathrm{w} / \mathrm{Ya}) *(\mathrm{Va} / \mathrm{VC}) \\
\text { (Richardson and other, 1995, p. 144 }\end{array}$ & $\begin{array}{l}\wedge .6031 \\
-146)\end{array}$ & & & & \\
\hline & Q100 & Q500 & OtherQ & & \\
\hline Q, total, cfs & 1190 & 2190 & 1080 & & \\
\hline Q, thru bridge $M C$, cfs & 1140 & 1269 & 1080 & & \\
\hline Vc, critical velocity, ft/s & 10.35 & 10.87 & 10.29 & & \\
\hline Va, velocity MC approach, ft/s & 5.32 & 5.27 & 5.05 & & \\
\hline Main channel width (normal), ft & 24.9 & 25.7 & 24.8 & & \\
\hline Cum. width of piers in MC, ft & 0.0 & 0.0 & 0.0 & & \\
\hline w, adjusted width, ft & 24.9 & 25.7 & 24.8 & & \\
\hline qbr, unit discharge, ft2/s & 45.8 & 49.4 & 43.5 & & \\
\hline Area of full opening, ft2 & 109.3 & 174.8 & 101.9 & & \\
\hline Hb, depth of full opening, ft & 4.39 & 6.80 & 4.11 & & \\
\hline Fr, Froude number, bridge $\mathrm{MC}$ & 0 & 0.51 & 0 & & \\
\hline Cf, Fr correction factor $(<=1.0)$ & 0.00 & 1.00 & 0.00 & & \\
\hline **Area at downstream face, ft2 & $\mathrm{N} / \mathrm{A}$ & 172 & $\mathrm{~N} / \mathrm{A}$ & & \\
\hline **Hb, depth at downstream face, ft & $\mathrm{N} / \mathrm{A}$ & 6.69 & $\mathrm{~N} / \mathrm{A}$ & & \\
\hline **Fr, Froude number at DS face & ERR & 0.50 & ERR & & \\
\hline$* *$ Cf, for downstream face $(<=1.0)$ & $\mathrm{N} / \mathrm{A}$ & 1.00 & $\mathrm{~N} / \mathrm{A}$ & & \\
\hline Elevation of Low Steel, ft & 0 & 498.71 & 0 & & \\
\hline Elevation of Bed, ft & -4.39 & 491.91 & -4.11 & & \\
\hline Elevation of Approach, ft & 0 & 500.02 & 0 & & \\
\hline Friction loss, approach, ft & 0 & 0.33 & 0 & & \\
\hline Elevation of WS immediately US, ft & 0.00 & 499.69 & 0.00 & & \\
\hline ya, depth immediately US, ft & 4.39 & 7.78 & 4.11 & & \\
\hline Mean elevation of deck, ft & 0 & 503.32 & 0 & & \\
\hline w, depth of overflow, ft $(>=0)$ & 0.00 & 0.00 & 0.00 & & \\
\hline
\end{tabular}




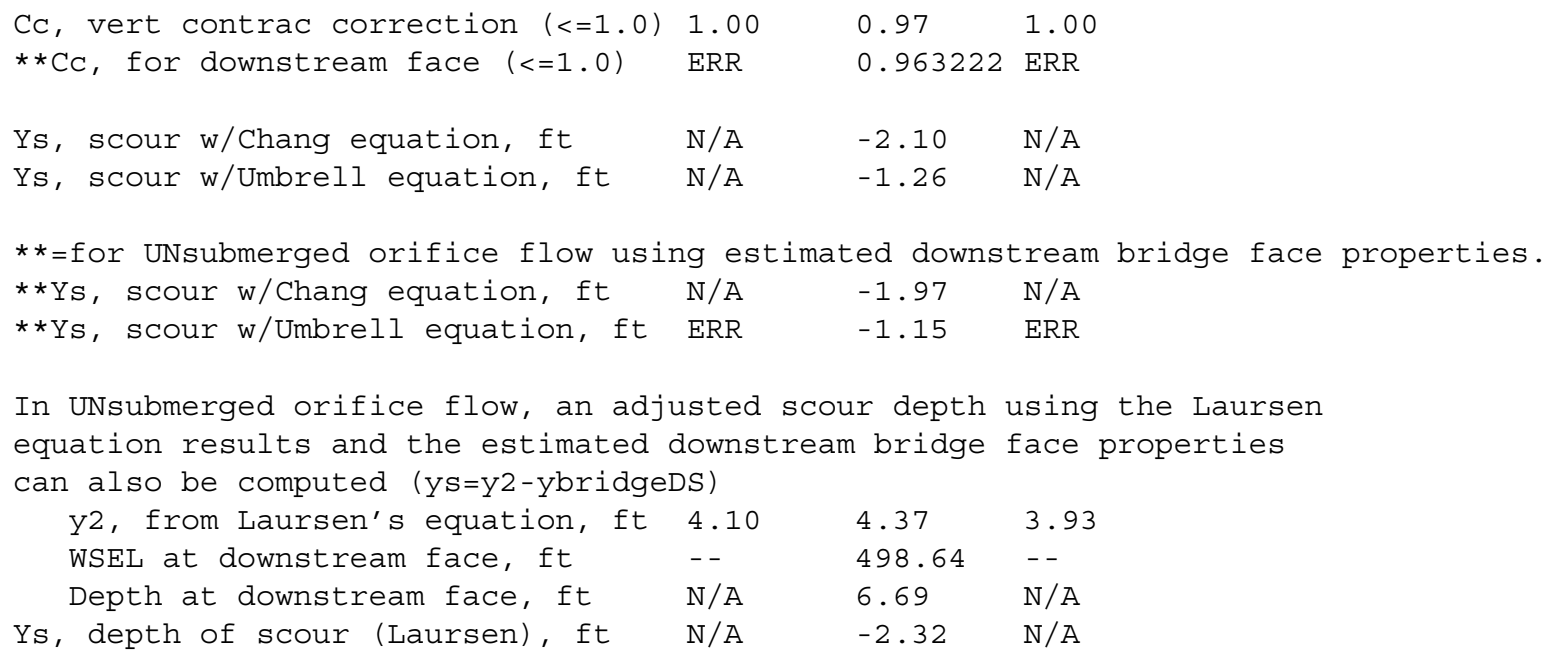

Abutment scour

Froehlich's Abutment Scour

$\mathrm{Ys} / \mathrm{Y} 1=2.27 * \mathrm{~K} 1 * \mathrm{~K} 2 *\left(\mathrm{a}^{\prime} / \mathrm{Y} 1\right) \wedge 0.43 * \mathrm{Fr} 1 \wedge 0.61+1$

(Richardson and others, 1995, p. 48, eq. 28)

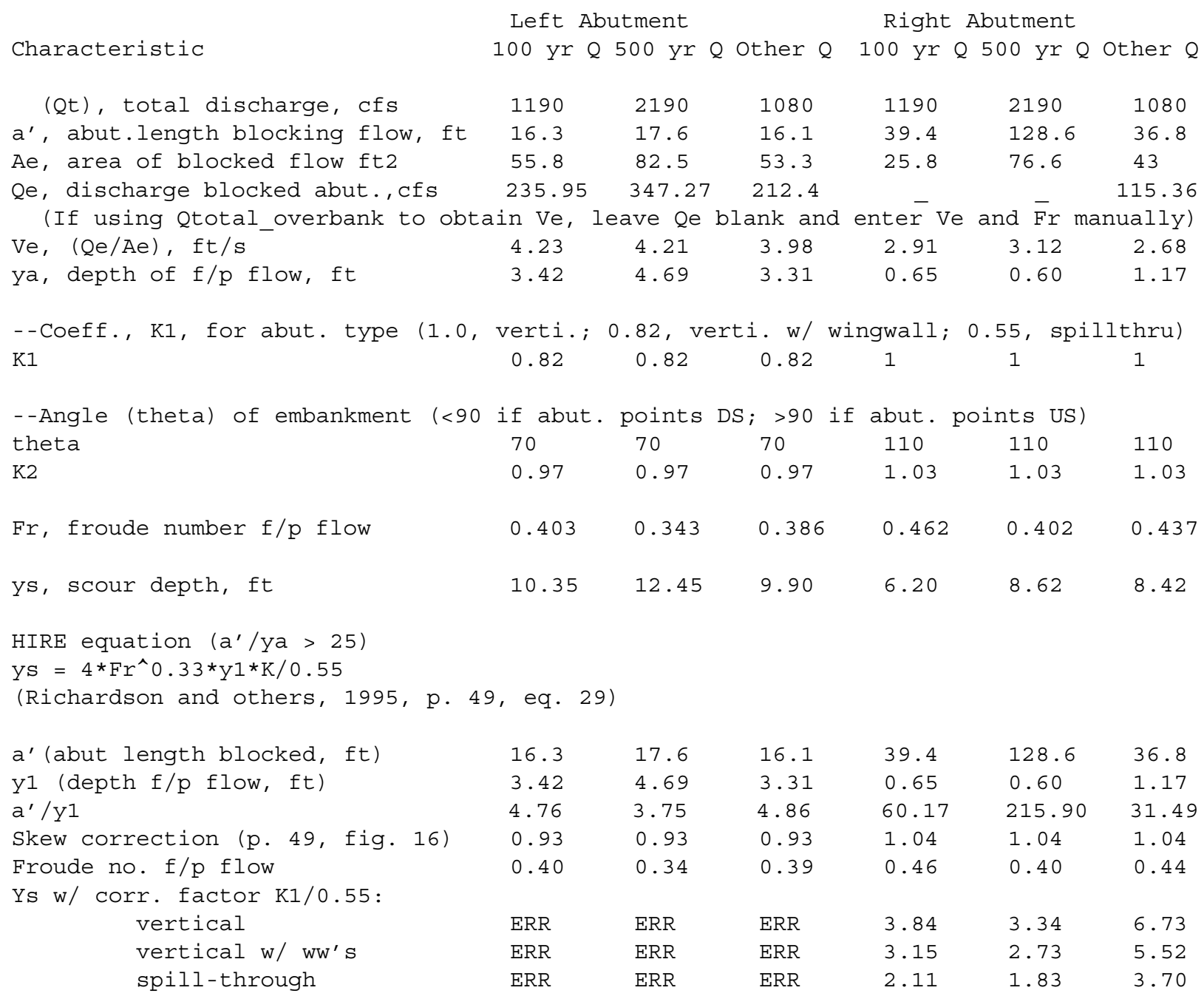




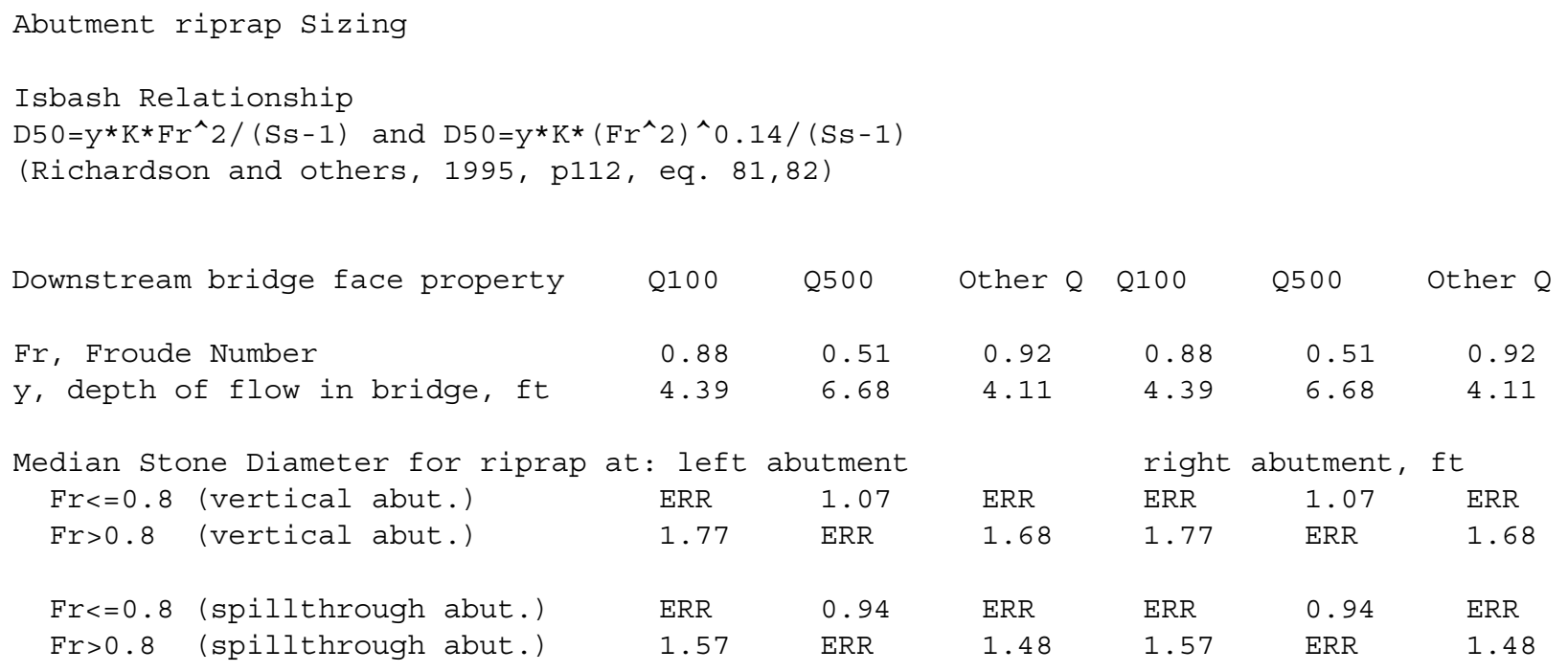

